Kennesaw State University

DigitalCommons@Kennesaw State University

Master of Science in Civil Engineering Theses

Department of Civil and Construction

Engineering

Spring 5-3-2019

\title{
A Comparative Study of Insertion Loss of Traffic Noise Barriers in Georgia
}

Pablo Giraldo

Jidong Yang

Follow this and additional works at: https://digitalcommons.kennesaw.edu/msce_etd

Part of the Civil Engineering Commons, Construction Engineering and Management Commons, Environmental Engineering Commons, and the Transportation Engineering Commons

\section{Recommended Citation}

Giraldo, Pablo and Yang, Jidong, "A Comparative Study of Insertion Loss of Traffic Noise Barriers in Georgia" (2019). Master of Science in Civil Engineering Theses. 5.

https://digitalcommons.kennesaw.edu/msce_etd/5

This Thesis is brought to you for free and open access by the Department of Civil and Construction Engineering at DigitalCommons@Kennesaw State University. It has been accepted for inclusion in Master of Science in Civil Engineering Theses by an authorized administrator of DigitalCommons@Kennesaw State University. For more information, please contact digitalcommons@kennesaw.edu. 


\title{
A Comparative Study of Insertion Loss of Traffic Noise Barriers
}

\author{
By
}

\section{Pablo Giraldo}

\begin{abstract}
A Master's Thesis submitted to the Faculty of Southern Polytechnic School of Engineering \& Engineering Technology
\end{abstract}

Kennesaw State University

Spring 2019 


\section{Contents}

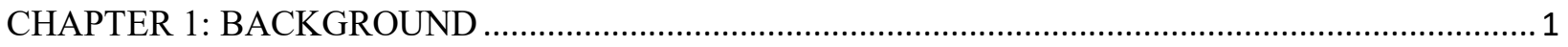

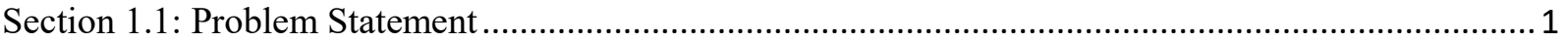

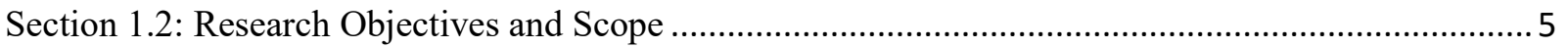

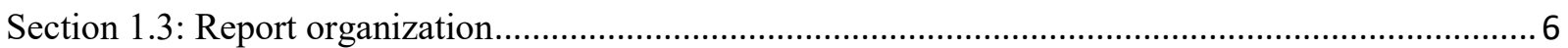

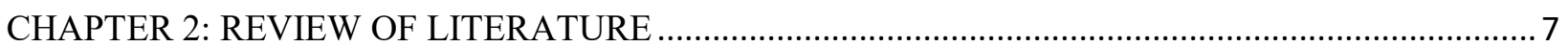

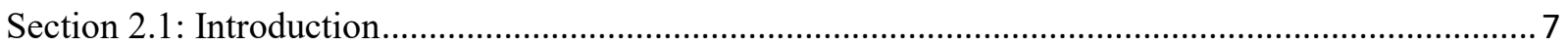

Section 2.2: Summary of Insertion Loss Study in Georgia .............................................................. 7

Section 2.3: Summary of Methods to Mitigate Noise Propagation ….................................................. 10

Section 2.4: Alternative Noise Barrier Materials ............................................................................... 11

Section 2.5: Alternative Noise Modeling Techniques .................................................................... 16

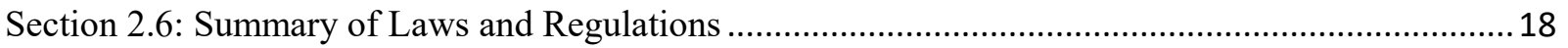

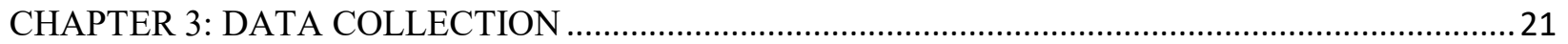

Section 3.1: Study Location and Material Composition .................................................................. 21

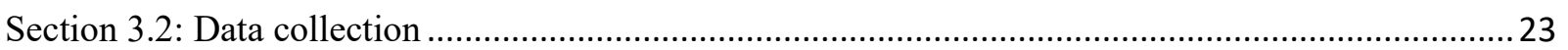

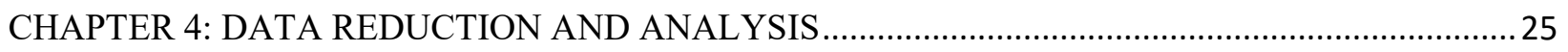

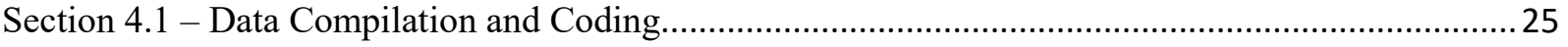

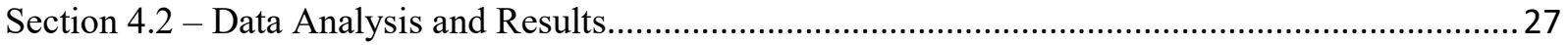

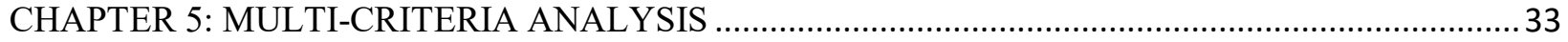

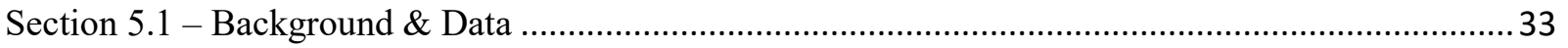

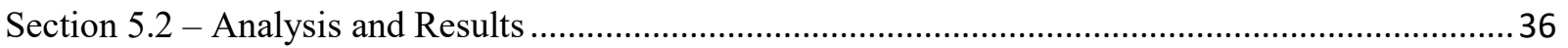

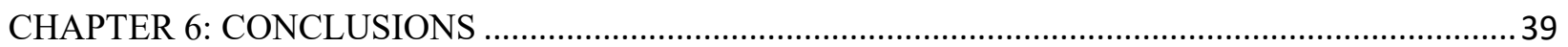

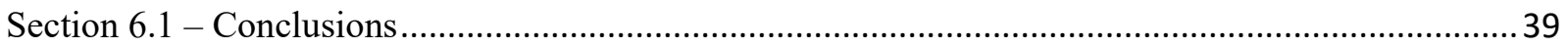

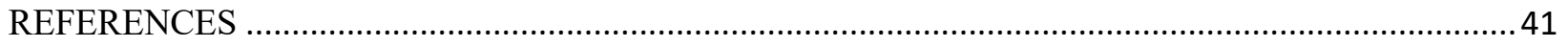

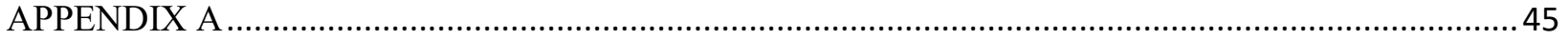

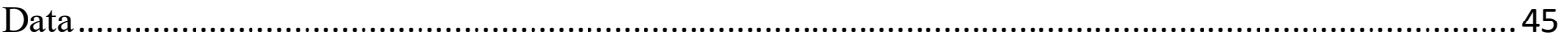

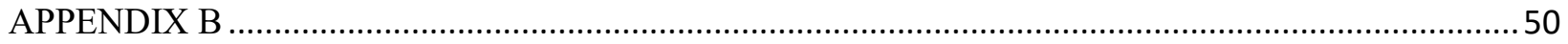

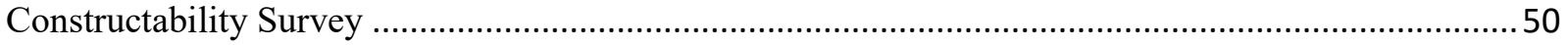




\section{List of Tables}

Table 1. GDOT Barrier Types (GDOT Section 6.24 -Sound Barriers) …................................ 4

Table 2. No Barrier Sound Levels (Harris \& Cohn, 2000) .................................................... 8

Table 3. With Barrier Sound Levels (Harris \& Cohn, 2000) .................................................... 9

Table 4. Parameters to Determine Noise Impact (FHWA, 2017) .......................................... 19

Table 5. Maximum Noise Emission Levels for Newly Manufactured Trucks (EPA, 2018)....... 20

Table 6. Maximum Noise Emission Levels for In Use Trucks (EPA, 2018) ............................ 20

Table 7. Description of Variables and Coding.................................................................... 27

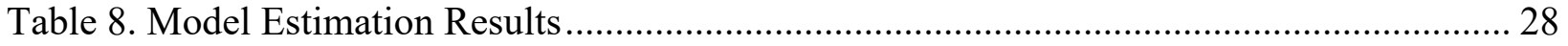

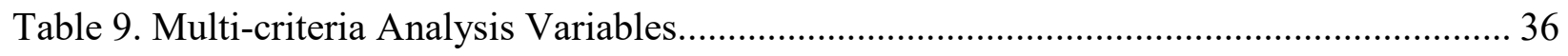

Table 10. Service Life of Noise Barriers (Morgan, et al., 2001) .............................................. 36

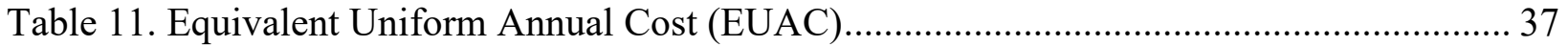

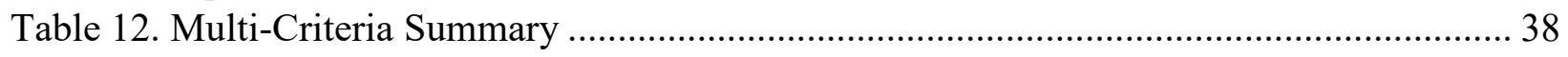




\section{List of Figures}

Figure 1. Noise Barrier Geometries (Kim \& Yoon, 2015) .................................................. 11

Figure 2. Location of Study Sites (Google Map) .............................................................. 21

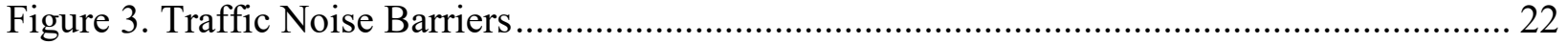

Figure 4. Noise Measurement Study at Site Locations........................................................ 24

Figure 5. Historical Weather (www.wunderground.com) ................................................. 25

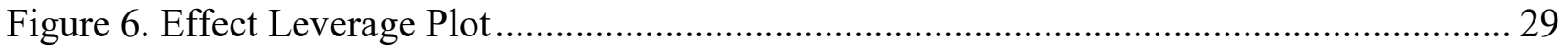

Figure 7. Q-Q Plot and Distribution of Standardized Residuals........................................... 30

Figure 8. Comparison of Insertion Loss of Traffic Noise Barriers. ........................................... 32

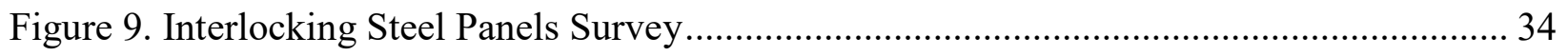

Figure 10. Precast Concrete Panels Survey ....................................................................... 34

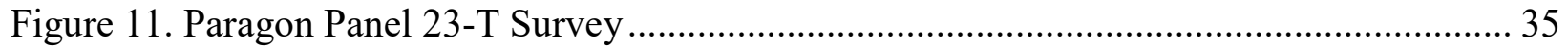

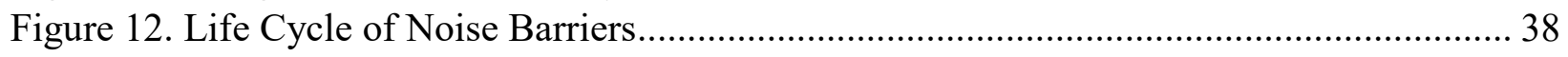




\section{CHAPTER 1: BACKGROUND}

\section{Section 1.1: Problem Statement}

Traffic noise is a nuisance to the quality of life. World health Organization (WHO, 2009) showed evidence on health damage of nighttime noise exposure. An annual average night exposure not exceeding $40 \mathrm{dBA}$ outdoors was recommended (WHO, 2011). A Day-Night Sound level (DNL) value of 65 DB has also been identified by the European Union as the threshold for negative health effects caused by noise (National Academy of Engineering, 2010). Traffic related noise is said to account for over 1 million healthy years of life lost annually to ill health and may lead to a disease burden that is second only in magnitude to that from air pollution (WHO, 2011). King and Davis (2003) highlighted traffic noise, as a particular source of noise, can cause various health problems such as sleep disturbance, high blood pressure and psychophysiological symptoms.

Traffic noise also plays an important role in the decision for locating real estate properties. Researchers have used reduction in property values as a means for estimating noise costs by correlating the increase in noise to property value depreciation. The impact ranged between $0.15 \%$ (in North Virginia) and 1.26\% (in Basel, Switzerland) for the Organization of Economic Cooperation and Development (OECD) countries. OECD recommends a depreciation of $0.5 \%$ in property value per $\mathrm{dBA}$ increase if levels are above $50 \mathrm{dBA}$ (Surahyo and El-Diraby, 2009).

As part of the recently completed Northwest Express project, different types of traffic noise barriers have been installed along the project to mitigate propagation of traffic noise to the adjacent properties. This project provides an opportunity to study the effectiveness of the 
selected noise barriers and evaluates a multi-criteria analysis incorporating cost, noise insertion loss values, and constructability. The noise barrier materials analyzed in this study are as follows:

- Interlocking Steel Panels: Also known as ShadowRib, the interlocking steel panels are a proven performer and a versatile tool to the designer. Structural strength in the ShadowRib panels is accomplished without sacrificing appearance or design flexibility. Apply the panels over light gauge framing, purlins, girts, structural steel and joists. Panels may be secured to the structure from the front or back of the structural steel with the ShadowRib concealed clip or with an expansion fastener. Both are positive fastened methods that create a secure interlock between panel and structure. The fluted face creates distinctive shadow lines (Metal Building Components, L.P., 2017).

- Precast Concrete Panels: Also known as Duratek Wall Systems are designed, manufactured, and installed to meet the highest standards of quality and engineering specifications. Made from structural fiber and steel-reinforced, high strength precast concrete, the pre-engineered walls exceed local and state building codes and are built to withstand wind loads up to $200 \mathrm{mph}$. Precast concrete stands as the most versatile and sustainable building solution, offering an almost endless variety of products and design options (Old Castle Precast, 2017).

- Paragon panel 23-T: Also known as Paragon, the panels are fabricated from expanded polystyrene core (EPS) coated with a polyurea structural coating, framed with 14-gauge steel and completely encapsulated with a second coat of the polyurea structural coating followed by a final weatherproof coating. The panels can achieve sound reduction levels of 15-40 dBA over a range of frequencies from 63 to $8000 \mathrm{~Hz}$. Furthermore, the panels 
have been designed and tested to withstand $163 \mathrm{mph}$ wind loads, are cost-effective, easily installed and water and insect resistant. The patent-pending product is revolutionary in the sound abatement industry. The extensive benefits of Paragon include absorption of $75 \%$ of the road noise, $40 \%$ of the product is made from recycled materials, and the aesthetically pleasing designs will surprise and delight citizens (Paragon Noise Barriers, 2017).

QPL - 90 included the three noise barrier products described until March 27, 2017 when the Paragon panel 23-T material was removed. The noise barrier products presented met GDOT's section 624 described below:

Section 624 - Sound Barriers

624.1 General Description

This work includes furnishing and installing a sound barrier according to this Specification and conforming to the locations, dimensions, lines, and grades shown on the Plans.

Unless a specific type is required by the Contract documents, select one of the following barrier types. Identify in the Proposal the type upon which the bid is based. 
Table 1. GDOT Barrier Types (GDOT Section 6.24 -Sound Barriers)

\begin{tabular}{|l|l|}
\hline Type $A$ & Concrete masonry units \\
\hline Type B & Interlock steel panels \\
\hline Type C & Precast concrete panels \\
\hline Type $D$ & Treated timber panels \\
\hline Type $E$ & Masonry-coated polystyrene reinforced panels \\
\hline Type $F$ & Glass reinforced thermoset composite structural panels \\
\hline Type $G$ & Precast autoclaved aerated concrete (PAAC) panels \\
\hline
\end{tabular}

Schedule construction as specified in the Special Provision for sequence of operation, the Plans, or as directed by the Engineer.

The Interlocking Steel panels, Precast Concrete panels, and Paragon panels 23-T were evaluated by the GDOT's Office of Materials and Testing and proved their capability of meeting the requirements of the Bridge Design Office and satisfied the requirements of SOP17, “Acceptance of Miscellaneous Construction Items.” (GDOT, 2016)

Assuming the description of each material remains true based on each vendor's facts, the purpose of this research identifies performance of the panel materials on the Interstate 75 and 575 Northwest Express project. This study utilizes R software (R Core Team 2019) to statistically analyze the data collected in the field to derive an intuitive engineering conclusion. 


\section{Section 1.2: Research Objectives and Scope}

The GDOT Noise Abatement Policy states that a noise barrier is considered feasible if it would reduce noise levels by $5 \mathrm{dBA}$ or more at one or more impacted sites, would be no more than 30 feet in height, and would allow appropriate access to adjacent properties (GDOT 2016). Technology for a Quieter America study in the Design and Performance section, specifies that information on the technical aspect of the barrier design and evaluation are available in The International Institute of Noise Control Engineering, 1999 (INCE,1999) and FHWA (2009d). In the INCE 1999 document, the best estimate by the working group that prepared it was that barrier insertion loss (the difference in A-weighted sound pressure level before and after installation of a barrier) typically ranges from 5 to 12 dBA. FHWA (2009d) classifies the insertion loss (attenuation) as follows:

- $5 \mathrm{~dB}=$ simple

- $10 \mathrm{~dB}=$ attainable

- $15 \mathrm{~dB}=$ very difficult

- $20 \mathrm{~dB}=$ nearly impossible

The objective of this research is to determine the noise insertion loss of each panel material interacting with influential variables, including the pavement type (concrete versus asphalt), traffic level (heavy or light), wind speed, and the distance of the noise barrier from the nearest edge of pavement of the highways, indicating how far the barrier is from the traffic. The ultimate goal of this research is to provide an opportunity to study the effectiveness of the selected noise barriers on the Northwest Express project, and to validate their compliance with the GDOT's Noise Abatement Policy. 


\section{Section 1.3: Report organization}

Chapter 2 of this report includes a comprehensive summary of the available literature pertaining to noise abatement studies, methods used by state and federal agencies to mitigate noise, alternative noise barrier panel materials used in different countries, additional noise model methods, and laws and regulations of noise abatement. Chapter 3 covers the study locations and data collection in the field. Furthermore, Chapter 4 analyses the data and explains the results. Chapter 5 discusses the multi-criteria analysis performed. Finally, Chapter 6 discusses the conclusions of the research and future analyses needed to expand this research. 


\section{CHAPTER 2: REVIEW OF LITERATURE}

\section{Section 2.1: Introduction}

Noise Abatement Policies that take into consideration implementing noise barriers in highway projects include the following (GDOT, 2016):

- Physical alteration of an existing highway's vertical or horizontal alignment.

- The addition of traffic lanes.

- The addition or relocation of interchange lanes or ramps added to a quadrant to complete an existing partial interchange.

- The addition of a new or substantial alteration of a weigh station, rest stop, rideshare lot or toll plaza.

Chapter 2 includes a comprehensive literature review on insertion loss studies, various methods to mitigate noise propagation from vehicles traveling on the interstates, and laws and regulations set in place for noise barriers.

\section{Section 2.2: Summary of Insertion Loss Study in Georgia} Harris and Cohn, 2000

On March 30, 1998, the FHWA released the Traffic Noise Model (TNM) version 1.0, which was the FHWA's new computer program for highway noise prediction and analysis. The components of the TNM were supported by a scientifically founded and experimentally calibrated acoustic computation methodology, as well as an entirely new, and more flexible data base, as compared with that of its predecessor, STAMINA 2.0/OPTIMA. A draft version of TNM 3.0 was released on March 14, 2017 and was available until September 30, 2017 for public 
comment. Until TNM 3.0 is fully made available to the public, the latest version is TNM 2.5.

The study conducted in the State of Georgia compares both methods and presents insertion loss values gathered from field tests.

\section{Site Determination for Highway Project in Georgia}

It was decided to conduct the study within the Atlanta metropolitan area because of consistent traffic flow conditions, and an abundance of suitable sites (both with and without barriers), and the availability of the GDOT's Advanced Traffic Management System traffic and speed data. Three sites were selected that included existing noise barriers, and three other sites were chosen that had no barriers.

No Barriers:

Multiple measurements were made at each site on August 4 and 5, 1998, and accomplished under the guidelines contained in "Measurement of Highway-Related Noise" (Lee and Fleming 1996). The measurements at each no-barrier site were averaged and are presented in Table 2 with the corresponding computer predictions for the same receiver.

Table 2. No Barrier Sound Levels (Harris \& Cohn, 2000)

\begin{tabular}{|c|c|c|c|c|c|c|c|}
\hline \multicolumn{8}{|c|}{ Measured versus Predicted Sound Levels $\left(L_{\text {eq }}\right)$, No Barrier } \\
\hline $\begin{array}{l}\text { Site } \\
\text { (1) }\end{array}$ & $\begin{array}{l}\text { Measured } \\
\text { level } \\
\text { (2) }\end{array}$ & $\begin{array}{c}\text { FHWA } \\
\text { STAMINA } \\
\text { (3) }\end{array}$ & $\begin{array}{c}\text { Difference } \\
\text { (measured } \\
\text { STAMINA) } \\
(4)\end{array}$ & $\begin{array}{c}\text { Georgia } \\
\text { STAMINA } \\
\text { (5) }\end{array}$ & $\begin{array}{c}\text { Difference } \\
\text { (measured } \\
\text { STAMINA) } \\
(6)\end{array}$ & $\begin{array}{c}\text { TNM } \\
(7)\end{array}$ & $\begin{array}{c}\text { Difference } \\
\text { (measured } \\
\text { TNM) } \\
(8)\end{array}$ \\
\hline $\begin{array}{l}1 \\
2 \\
4\end{array}$ & $\begin{array}{l}66.6 \\
73.6 \\
70.1\end{array}$ & $\begin{array}{l}71.4 \\
75.2 \\
71.1\end{array}$ & $\begin{array}{l}-4.8 \\
-1.6 \\
-1.0\end{array}$ & $\begin{array}{l}68.3 \\
73.5 \\
68.5\end{array}$ & $\begin{array}{l}-1.7 \\
+0.1 \\
+1.6\end{array}$ & $\begin{array}{l}68.7 \\
78.5 \\
72.8\end{array}$ & $\begin{array}{l}-2.1 \\
-4.9 \\
-2.7\end{array}$ \\
\hline Average difference & - & - & -2.5 & - & 0.0 & - & -3.2 \\
\hline
\end{tabular}




\section{With Barriers:}

The consideration of noise prediction accuracy with barriers in place were examined from two different perspectives. First, measurements were made and compared to model predictions at the same location, without regard for the actual barrier design the model would lead the user to develop. Second, barriers were designed on an actual project (I-475 in Macon, Ga.), using both STAMINA/OPTIMA and TNM. The resulting measurements at each with-barrier site were averaged and presented in Table 3.

Table 3. With Barrier Sound Levels (Harris \& Cohn, 2000)

\begin{tabular}{|c|c|c|c|c|c|c|c|}
\hline $\begin{array}{c}\text { Site } \\
\text { (1) }\end{array}$ & $\begin{array}{l}\text { Measured } \\
\text { level } \\
(2)\end{array}$ & $\begin{array}{c}\text { FHWA } \\
\text { STAMINA } \\
(3)\end{array}$ & $\begin{array}{c}\text { Difference } \\
\text { (measured } \\
\text { STAMINA) } \\
\text { (4) }\end{array}$ & $\begin{array}{c}\text { Georgia } \\
\text { STAMINA } \\
(5)\end{array}$ & $\begin{array}{c}\text { Difference } \\
\text { (measured } \\
\text { STAMINA) } \\
(6)\end{array}$ & $\begin{array}{c}\text { TNM } \\
(7)\end{array}$ & $\begin{array}{c}\text { Difference } \\
\text { (measured } \\
\text { TNM) } \\
(8)\end{array}$ \\
\hline $\begin{array}{l}3 \\
5 \\
6\end{array}$ & $\begin{array}{l}61.6 \\
58.8 \\
54.8\end{array}$ & $\begin{array}{l}62.1 \\
61.4 \\
56.2\end{array}$ & $\begin{array}{l}-0.5 \\
-2.6 \\
-1.4\end{array}$ & $\begin{array}{l}59.6 \\
59.6 \\
54.7\end{array}$ & $\begin{array}{l}+2.0 \\
-0.8 \\
+0.1\end{array}$ & $\begin{array}{l}63.1 \\
62.3 \\
55.7\end{array}$ & $\begin{array}{l}-1.5 \\
-3.5 \\
-0.9\end{array}$ \\
\hline Average difference & - & - & -1.5 & - & +0.4 & - & -2.0 \\
\hline
\end{tabular}

\section{Conclusion of Study}

Although the overall purpose of Harris and Cohn's study of taking measurements at three sites with no barriers, and at three separate sites with barriers, was to compare the effectiveness of TNM 1.0 versus the previous noise analysis program STAMINA 2.0/OPTIMA, the results of the data collected in the study presented in this paper have corresponding results to that of Harris and Cohn's study. Similar dBA values were collected in both studies considering the inflation in traffic from 1998 to 2018. As shown in the "Measured level" column of Tables 2 and 3, dBA 
values range from 54.8 to 73.6 , which mirror the values presented in this study. Moreover, for the experiment in this paper, similar challenges were faced during field data collection leading to minor dBA deviations.

\section{Section 2.3: Summary of Methods to Mitigate Noise Propagation}

Kim and Yoon, 2015

A unique approach at reducing noise levels is by altering the traditional shape of a wall. Many researchers have investigated the pressure attenuation phenomena of noise barriers under various geometric, material, and boundary conditions. To improve the pressure attenuation performance of noise barriers, size and shape optimization have been applied, and acoustic topology optimization (ATO) methods have been proposed that allow concurrent size, shape, and topological changes of rigid walls and cavities.

Compared with other measures, noise barriers are a lightweight, easy to install, and costeffective way to moderate noise pollution. Noise barriers are therefore commonly used for the most public applications to provide noise absorption and sound reflection. To calculate the efficiency of a noise barrier accurately, with the hope of building a better barrier, much fundamental and experimental research has been conducted. Most of this research has concluded that the common T-shaped barrier shown in Figure 1 has the most effective geometry, and some research has been conducted to heuristically change the details of its geometric parameters to optimize acoustic attenuation in a number of noise environments. In addition, some extended research has been done to change the profiles of the upper surface of a T-shape barrier with both rigid and porous structures. 
(a)

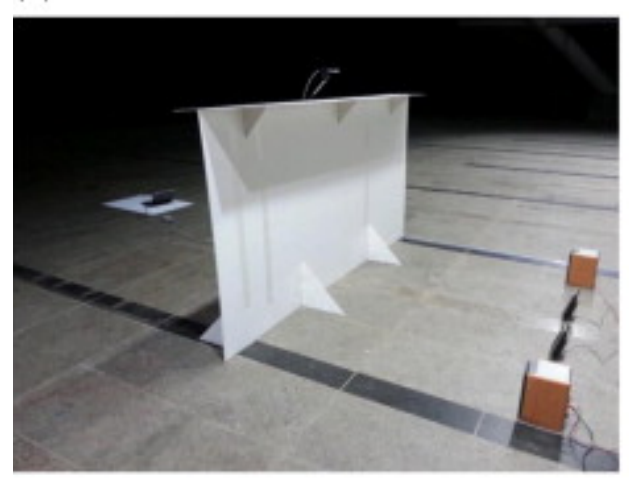

(c)
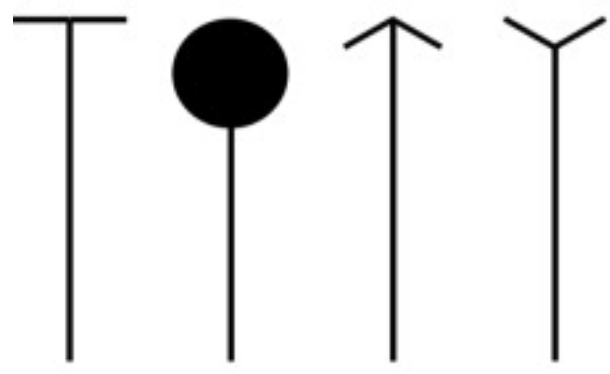

(b)

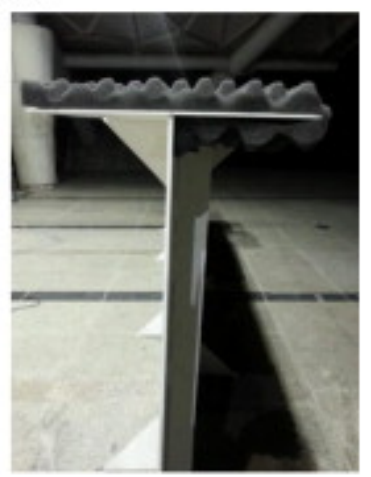

(d)

Figure 1. Noise Barrier Geometries (Kim \& Yoon, 2015)

Figure 1 shows (a)Noise barrier experiment with T-shaped barrier, (b) T-shaped barrier with porous material, (c) other barrier types (from left to right, T-shaped, cylinder-shaped, arrowshaped, and y-shaped), and (d) T-shaped barrier with quadratic residue diffuser (QRD).

\section{Section 2.4: Alternative Noise Barrier Materials}

Arenas et al., 2013

As industrial waste continues to accumulate, waste is becoming a major problem for the environment as well as for public health. In Spain, over 6\% of primary energy consumption came from coal in 2010, thus large amounts of by-products from coal power plants among them bottom ash, have been generated. From an environmental and economic point of view, the technical properties of bottom ash make their reuse appropriate and convenient. 
One of the most common materials used for highway noise barrier applications is a combination of porous concrete with a hard backing of standard concrete. Porous concrete is made by mixing large aggregate material with mortar, creating lots of voids in the cast concrete. As a result, the pores inside the material absorb sound energy through internal friction.

The objective of this study is to design a product composed mainly of bottom ash, so that it can be applied in the field of highway noise barriers. In order to achieve the greatest acoustic insulating behavior of the product, the influence of grain particle size of bottom ash, the thickness of the panel and the combination of different layers with various particle sizes have been studied.

The conclusions made from the study include, the grain particle size of bottom ash influenced the acoustic behavior and the physical and mechanical properties of the product made from bottom ash. The best sound absorption coefficients have been measured in products made from the larger bottom ash particles sizes, with high porosity. On the other hand, good mechanical properties have been found in the products made from the finest particles.

Also, the acoustic absorption coefficient spectra depend on the thickness of the specimen tested. The principal maximum of the absorption coefficient displaced to lower frequencies when the thickness increased.

Additionally, the combination of the three different bottom ash particle size fractions allowed the whole bottom ash to be recycled and gave a product which has been optimized for sound absorption. The product was composed of a wide layer containing the larger bottom ash particles in the incident noise face of the product, followed by the material made using the medium bottom ash particles size and finally, the fines bottom ash particles size material. The 
bottom ash product thus developed presented better sound absorbing behavior than a porous concrete reference product.

Finally, coal and pet-coke co-combustion bottom ash could thus be recycled as highway noise barriers in view of the results obtained. The product made of $80 \%$ bottom ash showed similar properties to other conventional materials used in this application.

Berto et al., 2015

In producing noise control elements, it is not only important to recycle but also to manufacture devices with recycled material. When designing noise barriers, a sound absorbing material is very often used as the core of the barrier. The main goal of this research was to design and test a novel green sound absorbing material used as part of noise barriers. Recycled textile materials and nontoxic binder fibers were employed to manufacture the eco-materials studied in this research. Acoustic characterization of prototype noise barriers was carried out in a custom designed small-scale reverberation chamber for the testing of small samples.

The conclusion of this research showed that the new materials used in noise barrier prototypes performed very well according to international standards, with performance comparable with those of commercially available noise barriers made of typical sound absorbing materials. 
Lopez et al., 2017

The objective of this research was to determine and evaluate the use of a mixture of shredded palm tree pruning waste with dampened topsoil in the construction of noise barriers. With a view to efficiently recycling pruning waste and using an environmentally-friendly material which does not pose any environmental risks at the end of its useful life, the composition offering the best sound absorption was analyzed. Based on the results obtained, a completely eco-friendly roadside noise barrier 1:1 scale model was built, and noise levels measured at various points close to it. Significant sound absorption benefits were detected, not only in the shaded area behind the barrier, but also in the unprotected area immediately above the barrier. Furthermore, the economic feasibility of both the construction and recycling processes were calculated.

An interesting approach was taken since the composition the noise barrier offers the best sound absorption analyzed during multiple tests. Built with a trapezoidal shape, the barrier is then covered with an agave cord mesh to give it rigidity and stability to the materials used. This research puts every existing material into perspective, as the least thought of materials might be the most successful ones.

Lacasta et al., 2016

Green noise barriers have become an alternative means of reducing urban traffic noise. In this paper, the acoustic performance of a modular greenery noise barrier was evaluated. In situ measurements of noise reflection were performed using an experimental prototype to estimate the sound absorption coefficients. These coefficients were found to have values of 
approximately 0.7 , higher than those previously found in laboratory measurements for a similar system with a lower vegetation density. The obtained values were input into software for predicting environmental noise to analyze the expected performance of such barriers, particularly in the case of a pair of parallel barriers. A comparison with the results for reflective barriers indicated a significant improvement in sound attenuation of up to $4 \mathrm{dBA}$. The values were similar and even superior to results reported by other authors regarding the effectiveness of absorptive treatments applied to parallel barriers, and furthermore, the proposed barriers offer an aesthetic element for environmental integration.

\section{Debije et al., 2018}

In this research two large-scale luminescent solar concentrator (LSC) noise barriers placed in an outdoor environment were monitored for over a year. Comparisons were made for the performances of a number of attached photovoltaic cells with changing spectral illumination, cloud cover conditions and other seasonal variations, and the temperatures of the cells. Differences in performance were attributed to the positioning of the panels, whether facing North/South or East/West. In general, the panels facing East/West ran cooler than those facing North/South. The LSCs in both orientations appeared to perform more efficiently under lower light conditions. One factor contributing to this increased performance was better spectral matching of the solar spectrum under cloudy conditions to the absorption spectrum of the embedded fluorescent dye. This work is a step forward in the characterization of a large-scale LSC device. This work also suggests predictions of performance of devices could be made for any location given sufficient knowledge of the illumination conditions and provides an important 
step towards the commercialization of these alternative solar energy generators for the urban setting.

\section{Section 2.5: Alternative Noise Modeling Techniques}

Reiter et al., 2017

The simulation-based prediction of intrinsic acoustic properties allows a cost-efficient product optimization in the course of the development process of noise barriers. The computational determination of the reflection index requires the simulation of the internal structure of a noise barrier by the finite-element method (FEM). The frequency range of interest and the mathematical modeling depth of the simulation result in a high computational effort which can be reduced by taking advantage of the periodic structure of a noise barrier. A periodic FEM model allows the simulation of fine geometric structures and different materials in noise barriers, e.g., perforated plates and porous absorbers. In this study, the authors compared and evaluated three methods for determining the acoustic properties of noise barriers, i.e., the acoustic measurement, analytical calculation, and FEM simulation. The analytical calculation was the most efficient method although this method was not able to reproduce results from the acoustic measurement above $2000 \mathrm{~Hz}$. The numerical calculation by a periodic FEM was efficient and reproduced results from the acoustic measurement more accurately. 
Toledo et al., 2017

The approach of this research was based on the evolutionary multi-objective optimization (EMO) of very thin noise barrier models with improved performance idealized as single-wire designs. To assume such a simplification of reality, the dual boundary element (DBE) formulation for assessing the acoustic efficiency arises as the most appropriate strategy involving $\mathrm{BE}$ to avoid drawbacks associated with the exclusive implementation of the standard formulation (SBE). The 2D analysis performed in this work focused on the simultaneous optimization of two objectives in conflict using the Non-dominated Sorting Genetic Algorithm (NSGA-II): the maximization of noise attenuation and the minimization of the amount of material used in manufacturing the barrier, represented by the overall length of its elements. Under this framework, two optimization strategies were compared for each model with equal number of fitness evaluations: (1) when considering a random initial population and (2) when including the best single-objective optimal design in the initial population. The results obtained showed wide and uniformly spread-out non-dominated fronts, reflected in the geometric diversity featured by optimal designs; statistical analysis confirmed the advantages of the latter initial population strategy.

Kumar et al., 2014

This study applied artificial neural network (ANN) for the determination of optimized height of a highway noise barrier. Field measurements were carried out to collect traffic volume, vehicle speed, noise level, and site geometry data. Barrier height was varied from 2 to $5 \mathrm{~m}$ in increments of $0.1 \mathrm{~m}$ for each measured data set to generate theoretical data for network design. 
Barrier attenuation was calculated for each height increment using Federal Highway Administration model. For neural network design purpose, classified traffic volume, corresponding traffic speed, and barrier attenuation data were taken as input parameters, while barrier height was considered as output. ANNs with different architectures were trained, cross validated, and tested using this theoretical data. Results indicated that ANN can be useful to determine the height of noise barrier accurately, which can effectively achieve the desired noise level reduction, for a given set of traffic volume, vehicular speed, highway geometry, and site conditions.

\section{Section 2.6: Summary of Laws and Regulations}

FHWA

In the U.S., the Federal Highway Administration (FHWA) is the agency responsible for administering the Federal-aid highway program in accordance with Federal statutes and regulations. The FHWA developed the noise regulations as required by the Federal-Aid Highway act of 1970. Table 4 represents the dBAs that are used to determine impact. These dBAs are the absolute levels above which abatement must be considered. 
Table 4. Parameters to Determine Noise Impact (FHWA, 2017)

[Hourly A-Weighted Sound Level decibels, $d B(A)$ ]

\begin{tabular}{|c|c|c|c|}
\hline $\begin{array}{l}\text { Activity } \\
\text { Category }\end{array}$ & $\begin{array}{l}\text { Activity } \\
\text { Leq(h) }\end{array}$ & $\begin{array}{l}\text { Evaluation } \\
\text { Location }\end{array}$ & Activity Description \\
\hline A & 57 & Exterior & $\begin{array}{l}\text { Lands on which serenity and quiet are of extraordinary } \\
\text { significance and serve an important public need and where the } \\
\text { preservation of those qualities is essential if the area is to } \\
\text { continue to serve its intended purpose. }\end{array}$ \\
\hline $\mathrm{B}$ & 67 & Exterior & Residential \\
\hline C & 67 & Exterior & $\begin{array}{l}\text { Active sport areas, amphitheaters, auditoriums, campgrounds, } \\
\text { cemeteries, day care centers, hospitals, libraries, medical } \\
\text { facilities, parks, picnic areas, places of worship, playgrounds, } \\
\text { public meeting rooms, public or nonprofit institutional } \\
\text { structures, radio studios, recording studios, recreation areas, } \\
\text { Section } 4(f) \text { sites, schools, television studios, trails, and trail } \\
\text { crossings. }\end{array}$ \\
\hline D & 52 & Interior & $\begin{array}{l}\text { Auditoriums, day care centers, hospitals, libraries, medical } \\
\text { facilities, places of worship, public meeting rooms, public or } \\
\text { nonprofit institutional structures, radio studios, recording } \\
\text { studios, schools, and television studios. }\end{array}$ \\
\hline $\mathrm{E}$ & 72 & Exterior & $\begin{array}{l}\text { Hotels, motels, offices, restaurants/bars, and other developed } \\
\text { lands, properties, or activities not included in A-D or F }\end{array}$ \\
\hline $\mathrm{F}$ & - & - & $\begin{array}{l}\text { Agriculture, airports, bus yards, emergency services, } \\
\text { industrial, logging, maintenance facilities, manufacturing, } \\
\text { mining, rail yards, retail facilities, shipyards, utilities (water } \\
\text { resources, water treatment, electrical), and warehousing }\end{array}$ \\
\hline G & - & - & Undeveloped lands that are not permitted \\
\hline
\end{tabular}

Source: (Federal Highways Administration) (23 CFR 772)

The Noise Control Act of 1972 authorizes the U.S. Environmental Protection Agency

(EPA) to establish noise regulations to control major sources of noise, including transportation vehicles and construction equipment (FHWA, 2017). Additionally, this legislation requires EPA to issue noise emission standards for motor vehicles used in interstate commerce and required the Federal Motor Carrier Safety Administration to enforce these noise emission standards. The EPA established regulations, which set emission level standards for newly manufactured medium and heavy trucks with a gross vehicle weight rating (GVWR) greater than 10,000 pounds and capable 
of operating on a highway or street. Table 5 shows the maximum noise emission levels allowed by the EPA noise regulations for these vehicles.

Table 5. Maximum Noise Emission Levels for Newly Manufactured Trucks (EPA, 2018) Maximum Noise Emission Levels as Required by EPA for Newly Manufactured Trucks with GVWR Over 10,000 Pounds

\begin{tabular}{|c|c|}
\hline Effective Date & Maximum Noise Level 50 Feet from Centerline of Travel* \\
\hline January 1,1988 & $80 \mathrm{~dB}(\mathrm{~A})$ \\
\hline \multicolumn{2}{|c|}{ Using the Society of Automotive Engineers, Inc. (SAE), test procedure for } \\
acceleration under $35 \mathrm{mph}$
\end{tabular}

The Federal government also has authority to regulate noise emission levels for existing (in use) medium and heavy trucks with a GVWR of more than 10,000 pounds that are engaged in interstate commerce. Table 6 shows the EPA emission level standards for in use medium and heavy trucks engaged in interstate commerce.

Table 6. Maximum Noise Emission Levels for In Use Trucks (EPA, 2018)

Maximum Noise Emission Levels as Required by EPA for In Use Medium and Heavy Trucks with GVWR Over 10,000 Pounds Engaged in Interstate Commerce

\begin{tabular}{|c|c|c|}
\hline Effective Date & Speed & $\begin{array}{c}\text { Maximum Noise Level 50 Feet } \\
\text { from Centerline of Travel }\end{array}$ \\
\hline \multirow{3}{*}{ January 8,1986 } & $<35 \mathrm{mph}$ & $83 \mathrm{~dB}(\mathrm{~A})$ \\
\cline { 2 - 3 } & $>35 \mathrm{mph}$ & $87 \mathrm{~dB}(\mathrm{~A})$ \\
\cline { 2 - 3 } & Stationary & $85 \mathrm{~dB}(\mathrm{~A})$ \\
\hline
\end{tabular}




\section{CHAPTER 3: DATA COLLECTION}

Section 3.1: Study Location and Material Composition

The study presented in this paper was conducted along Interstates 75 and 575 in Cobb and Cherokee Counties on GDOT's Northwest Express Project as shown in Figure 2.

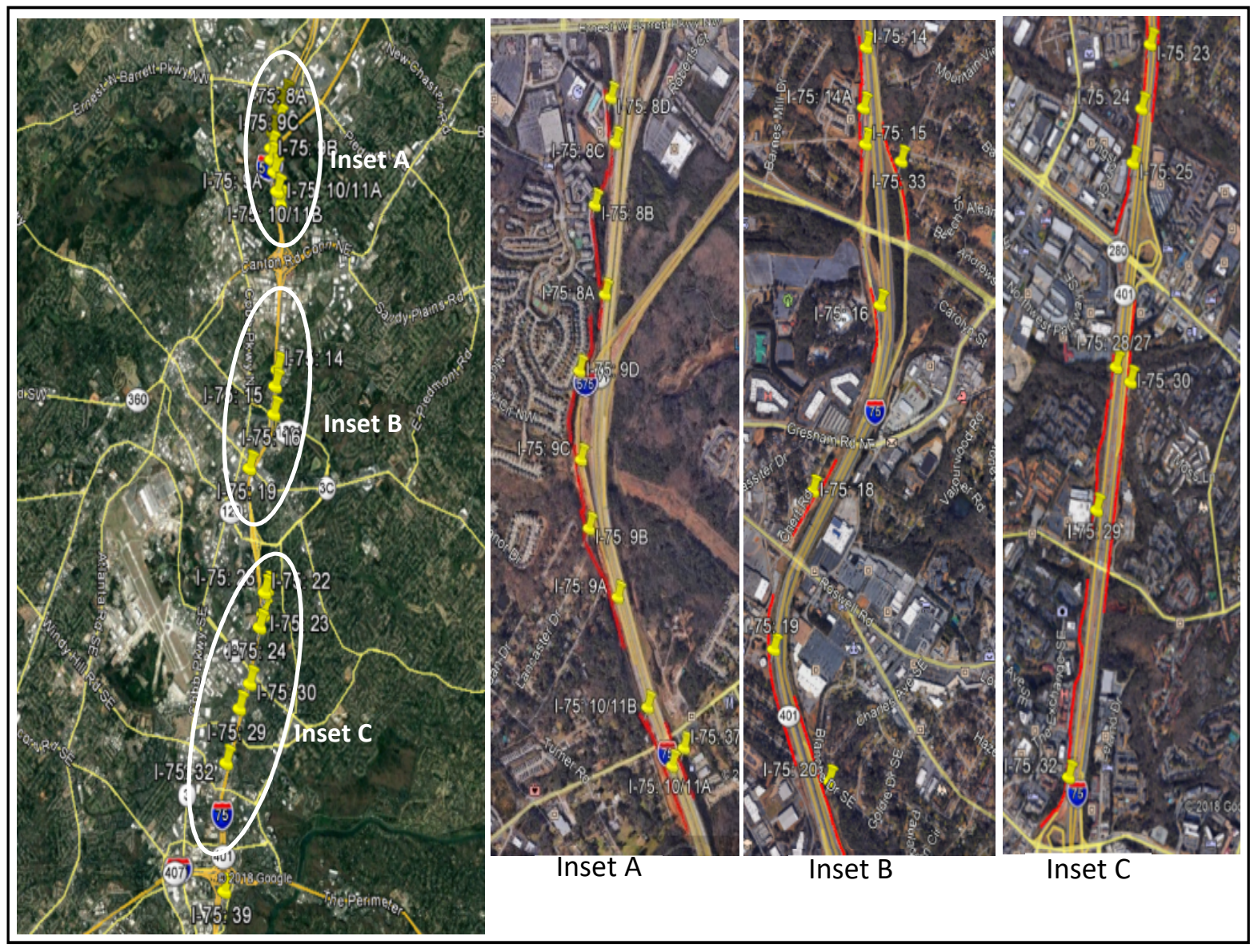

Figure 2. Location of Study Sites (Google Map) 
The data collected in the field pertains to noise barriers adjacent to the interstates in addition to noise barriers constructed next to GDOT's right of way, at an average distance of 121 feet from the edge of travel lanes on I-75. Three different noise barrier panel materials were selected to evaluate the $\mathrm{dBA}$ insertion loss. The measurement procedures conducted in this study are similar to those specified in FHWA's Measurement of Highway-Related Noise report (FHWA, 1996).

The noise barrier panel materials used in GDOT's project include three major types: (1) interlocking steel panels, also known as Shadow Rib for its design integrity and physical appearance, (2) precast concrete panels known as Duratek wall systems, fabricated from structural fiber and steel-reinforced high strength precast concrete, and (3) Paragon Panel 23-T, commonly known as Paragon, fabricated from expanded polystyrene core (EPS) coated with a polyurea structural coating, framed with 14-gauge steel and completely encapsulated with a second coat of the polyurea structural coating followed by a final weatherproof coating. Figure 3 shows photos of the three barriers took in the field.

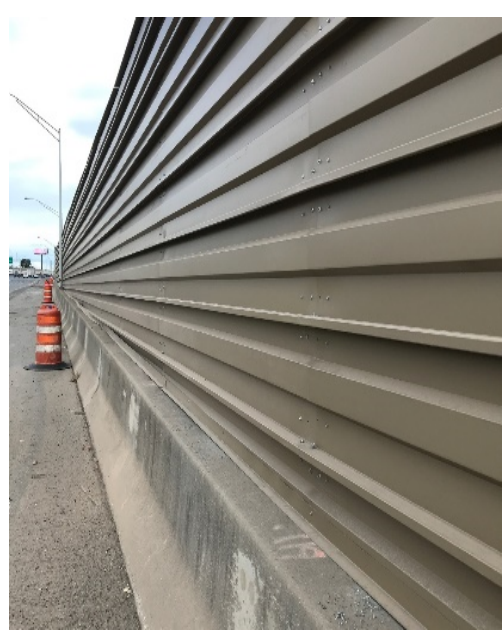

a) Interlocking Steel Panels

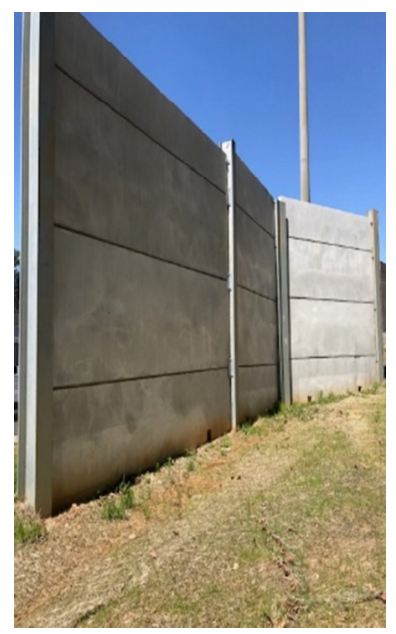

b) Precast Concrete Panels

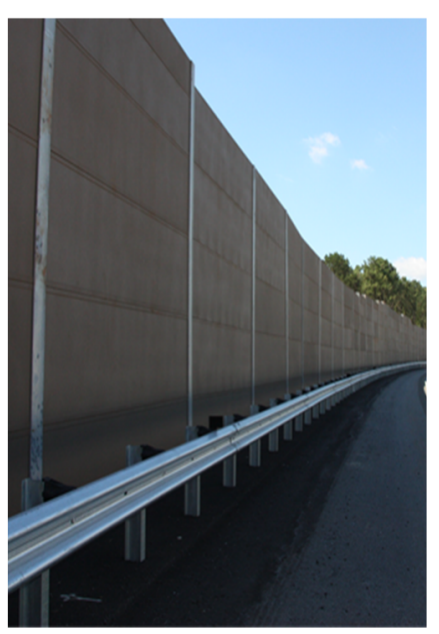

c) Paragon Panels 23-T

Figure 3. Traffic Noise Barriers 


\section{Section 3.2: Data collection}

It is essential to state that at the time the data was collected in the field, each noise barrier was already constructed, and no construction equipment was in close proximity that might have led to noise alterations. To determine the $\mathrm{dBA}$ insertion loss at each location, a sound level meter was used to collect dBA readings. During the months of June through September of 2018, samples were collected at random times during Monday through Friday. A tripod with the sound level meter was set up in front of and behind the noise barrier with a minimum interval of five minutes between each reading. The sound level meter used was set up to read a maximum and minimum dBA value of the noise sample in question. The maximum and minimum values were recorded in a field log, the values were averaged to obtain the dBA insertion loss, and then transferred into the "Results" table attached to this paper. The values obtained followed the insertion loss guidelines as described in Section 4.6-Data Analysis in FHWA's Noise Measurement Guidelines. Once the samples for the entire research were collected and transferred into the "Results" table, additional columns were added to include variables such as physical characteristics of each noise barrier and atmospheric data obtained from weatherunderground.com. At the time of the experiment, noise propagation was being measured from vehicles traveling on the general-purpose lanes on I-75 as the Express Lanes were not operational to the public. 


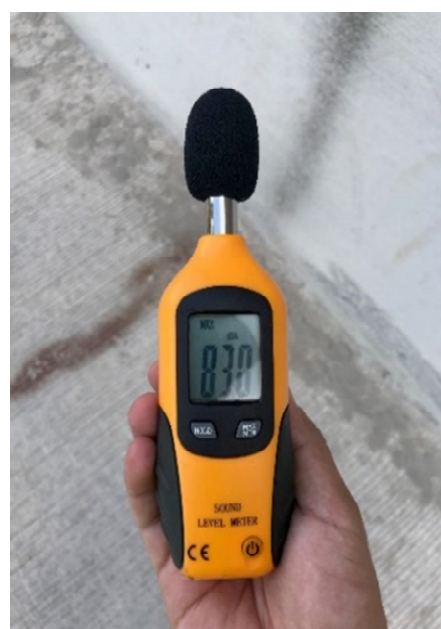

a) Sound Level Meter

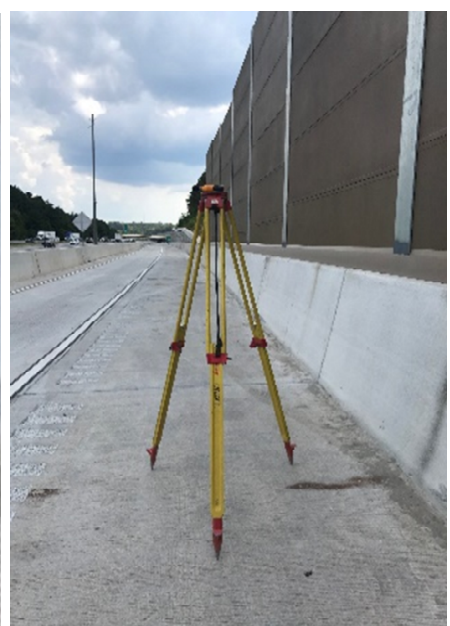

b) Noise measurement in front of the barrier

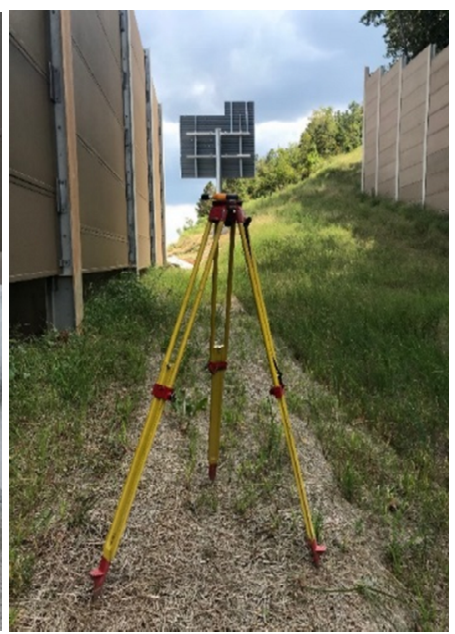

c) Noise measurement behind the barrier

Figure 4. Noise Measurement Study at Site Locations

Each reading was taken with a minimum sample time of 40 seconds to account for environmental noise and a mix of vehicles traveling on the interstates. The device used in the experiment was a Riserpro Mini Sound Level Meter (Fig. 4a). Samples were taken during peak and off-peak periods of traffic. Temperatures ranged from $64^{\circ} \mathrm{F}$ to $104^{\circ} \mathrm{F}$. Wind speeds were recorded in the range of $0.0 \mathrm{mph}$ to $11.0 \mathrm{mph}$. 


\section{CHAPTER 4: DATA REDUCTION AND ANALYSIS}

Section 4.1 - Data Compilation and Coding

Besides the noise data measurement described in Chapter 3, other relevant data were also noted during the field measurement, such as pavement types (asphalt or concrete) and traffic condition (heavy or light). Barrier height and installation location relative to traffic (i.e., the distance to the edge of nearest travel lane) were obtained from the noise barrier shop drawings for the Northwest Express project. Environmental factors, including wind speed, temperature, dew point, humidity, atmospheric pressure, precipitation rate and accumulation values were obtained from www.wunderground.com. A screen capture of the website is shown in Figure 5.

\section{Daily Observations}

\begin{tabular}{|c|c|c|c|c|c|c|c|c|c|c|}
\hline Time & Temperature & Dew Point & Humidity & Wind & Wind Speed & Wind Gust & Pressure & Precip. & Precip Accum & Condition \\
\hline 8:52 PM & $73^{\circ} \mathrm{F}$ & $69^{\circ} \mathrm{F}$ & $87 \%$ & NNE & $8 \mathrm{mph}$ & $0 \mathrm{mph}$ & 28.8 in & 0.1 in & 0.0 in & Light Rain \\
\hline 9:42 PM & $72^{\circ} \mathrm{F}$ & $68^{\circ} \mathrm{F}$ & $87 \%$ & $\mathrm{NE}$ & $6 \mathrm{mph}$ & $0 \mathrm{mph}$ & 28.8 in & 0.0 in & 0.0 in & Light Rain \\
\hline 9:52 PM & $72^{\circ} \mathrm{F}$ & $68^{\circ} \mathrm{F}$ & $87 \%$ & $\mathrm{NE}$ & $6 \mathrm{mph}$ & $0 \mathrm{mph}$ & 28.8 in & 0.0 in & 0.0 in & Cloudy \\
\hline 10:52 PM & $72^{\circ} \mathrm{F}$ & $68^{\circ} \mathrm{F}$ & $87 \%$ & $\mathrm{NE}$ & $10 \mathrm{mph}$ & $0 \mathrm{mph}$ & 28.8 in & 0.0 in & 0.0 in & Cloudy \\
\hline 11:52 PM & $71^{\circ} \mathrm{F}$ & $69^{\circ} \mathrm{F}$ & $93 \%$ & $\mathrm{E}$ & $9 \mathrm{mph}$ & $0 \mathrm{mph}$ & 28.8 in & 0.0 in & 0.0 in & Fair \\
\hline 12:17 AM & $71^{\circ} \mathrm{F}$ & $69^{\circ} \mathrm{F}$ & $93 \%$ & $E$ & $8 \mathrm{mph}$ & $0 \mathrm{mph}$ & 28.8 in & 0.0 in & 0.0 in & Cloudy \\
\hline $12: 52 \mathrm{AM}$ & $71^{\circ} \mathrm{F}$ & $69^{\circ} \mathrm{F}$ & $93 \%$ & $E$ & $8 \mathrm{mph}$ & $0 \mathrm{mph}$ & 28.8 in & 0.0 in & 0.0 in & Mostly Cloudy \\
\hline 1:52 AM & $71^{\circ} \mathrm{F}$ & $69^{\circ} \mathrm{F}$ & $93 \%$ & $E$ & $7 \mathrm{mph}$ & $0 \mathrm{mph}$ & 28.8 in & 0.0 in & 0.0 in & Cloudy \\
\hline 2:43 AM & $71^{\circ} \mathrm{F}$ & $68^{\circ} \mathrm{F}$ & $90 \%$ & $\mathrm{E}$ & $8 \mathrm{mph}$ & $0 \mathrm{mph}$ & 28.8 in & 0.0 in & 0.0 in & Mostly Cloudy \\
\hline 2:52 AM & $71^{\circ} \mathrm{F}$ & $68^{\circ} \mathrm{F}$ & $90 \%$ & $E$ & $8 \mathrm{mph}$ & $0 \mathrm{mph}$ & 28.8 in & 0.0 in & 0.0 in & Partly Cloudy \\
\hline 3:26 AM & $71^{\circ} \mathrm{F}$ & $68^{\circ} \mathrm{F}$ & $90 \%$ & $E$ & $8 \mathrm{mph}$ & $0 \mathrm{mph}$ & 28.9 in & 0.0 in & 0.0 in & Mostly Cloudy \\
\hline 3:43 AM & $72^{\circ} \mathrm{F}$ & $69^{\circ} \mathrm{F}$ & $91 \%$ & $E$ & $6 \mathrm{mph}$ & $0 \mathrm{mph}$ & 28.9 in & 0.0 in & 0.0 in & Mostly Cloudy \\
\hline 3:52 AM & $72^{\circ} \mathrm{F}$ & $68^{\circ} \mathrm{F}$ & $87 \%$ & ENE & $7 \mathrm{mph}$ & $0 \mathrm{mph}$ & 28.9 in & 0.0 in & 0.8 in & Mostly Cloudy \\
\hline 4:50 AM & $73^{\circ} \mathrm{F}$ & $68^{\circ} \mathrm{F}$ & $83 \%$ & $E$ & $8 \mathrm{mph}$ & $0 \mathrm{mph}$ & 28.9 in & 0.0 in & 0.0 in & Mostly Cloudy \\
\hline 4:52 AM & $74^{\circ} \mathrm{F}$ & $68^{\circ} \mathrm{F}$ & $82 \%$ & $E$ & $7 \mathrm{mph}$ & $0 \mathrm{mph}$ & 28.9 in & 0.0 in & 0.0 in & Mostly Cloudy \\
\hline 5:10 AM & $73^{\circ} \mathrm{F}$ & $68^{\circ} \mathrm{F}$ & $84 \%$ & ENE & $10 \mathrm{mph}$ & $0 \mathrm{mph}$ & 28.9 in & 0.0 in & 0.0 in & Mostly Cloudy \\
\hline 5:52 AM & $74^{\circ} \mathrm{F}$ & $69^{\circ} \mathrm{F}$ & $85 \%$ & ENE & $7 \mathrm{mph}$ & $0 \mathrm{mph}$ & 28.9 in & 0.0 in & 0.0 in & Cloudy \\
\hline 6:52 AM & $75^{\circ} \mathrm{F}$ & $67^{\circ} \mathrm{F}$ & $76 \%$ & ENE & $8 \mathrm{mph}$ & $0 \mathrm{mph}$ & 28.9 in & 0.0 in & 0.0 in & Cloudy \\
\hline $7: 52 \mathrm{AM}$ & $76^{\circ} \mathrm{F}$ & $68^{\circ} \mathrm{F}$ & $76 \%$ & ENE & $7 \mathrm{mph}$ & $0 \mathrm{mph}$ & 28.9 in & 0.0 in & 0.0 in & Cloudy \\
\hline 8:52 AM & $78^{\circ} \mathrm{F}$ & $68^{\circ} \mathrm{F}$ & $71 \%$ & $E$ & $5 \mathrm{mph}$ & $0 \mathrm{mph}$ & 28.9 in & $0.0 \mathrm{in}$ & 0.0 in & Mostly Cloudy \\
\hline $9: 20 \mathrm{AM}$ & $80^{\circ} \mathrm{F}$ & $68^{\circ} \mathrm{F}$ & $67 \%$ & $\mathrm{NE}$ & $8 \mathrm{mph}$ & $0 \mathrm{mph}$ & 28.9 in & 0.0 in & $0.0 \mathrm{in}$ & Mostly Cloudy \\
\hline 9:52 AM & $82^{\circ} \mathrm{F}$ & $69^{\circ} \mathrm{F}$ & $65 \%$ & VAR & $6 \mathrm{mph}$ & $0 \mathrm{mph}$ & 28.9 in & 0.0 in & $0.0 \mathrm{in}$ & Mostly Cloudy \\
\hline 10:52 AM & $83^{\circ} \mathrm{F}$ & $68^{\circ} \mathrm{F}$ & $60 \%$ & VAR & $3 \mathrm{mph}$ & $0 \mathrm{mph}$ & 28.9 in & 0.0 in & 0.0 in & Mostly Cloudy \\
\hline 11:52 AM & $84^{\circ} \mathrm{F}$ & $70^{\circ} \mathrm{F}$ & $63 \%$ & NW & $6 \mathrm{mph}$ & $0 \mathrm{mph}$ & 28.8 in & 0.0 in & 0.0 in & Mostly Cloudy \\
\hline 12:52 PM & $85^{\circ} \mathrm{F}$ & $69^{\circ} \mathrm{F}$ & $59 \%$ & NW & $8 \mathrm{mph}$ & $0 \mathrm{mph}$ & 28.8 in & 0.0 in & 0.0 in & Mostly Cloudy \\
\hline
\end{tabular}

Figure 5. Historical Weather (www.wunderground.com) 
For modeling purposes, dummy variables were created for panel materials (i.e., steel, concrete, Paragon panel 23-T), pavement types, and traffic conditions.

The resulting data set is presented in Appendix A. 


\section{Section 4.2 - Data Analysis and Results}

Since noise measurements were made at different locations and times, the variables that were influential to the noise variation were accounted for in the model specification. Statistical analysis revealed a number of influential variables, including the pavement type (concrete versus asphalt), traffic level (heavy or light), wind speed, and the distance of the noise barrier from the nearest edge of pavement of the highways, indicating how far the barrier is from traffic. Other weather-related variables, including dew point, humidity, atmosphere pressure, visibility, and precipitation, were also considered as part of the modeling process, but they turned out to be insignificant to explain noise variation. To evaluate the effects of different types of noise barriers, dummy variables were used. Those variables that are significant to the noise variation are summarized in Table 7.

Table 7. Description of Variables and Coding

\begin{tabular}{|c|c|c|c|c|c|c|}
\hline Variable & Description & Unit & Mean & Median & Min & Max \\
\hline Insertion Loss & $\begin{array}{l}\text { The measured noise reduction } \\
\text { due to the barrier }\end{array}$ & dBA & 10.03 & 10.53 & 3.45 & 18.75 \\
\hline Distance & $\begin{array}{l}\text { Distance from the noise } \\
\text { barrier to the pavement edge } \\
\text { of the highways }\end{array}$ & feet & 72.49 & 68 & 10 & 195 \\
\hline Wspeed & Wind speed & mile per hour & 0.92 & 0 & 0 & 11 \\
\hline Pavement & Pavement type & $\begin{array}{l}1=\text { asphalt; } \\
0=\text { concrete }\end{array}$ & 0.61 & 1 & 0 & 1 \\
\hline Traffic & Traffic condition & $\begin{array}{l}1=\text { heavy } \\
0=\text { light }\end{array}$ & 0.24 & 0 & 0 & 1 \\
\hline Paragon & Paragon panel 23-T & 1,0 otherwise & 0.4 & $\mathrm{n} / \mathrm{a}$ & 0 & 1 \\
\hline Concrete & Precast concrete panels & 1,0 otherwise & 0.19 & $\mathrm{n} / \mathrm{a}$ & 0 & 1 \\
\hline Steel & Interlocking steel panels & 1,0 otherwise & 0.41 & $\mathrm{n} / \mathrm{a}$ & 0 & 1 \\
\hline
\end{tabular}


The insertion losses due to the noise barriers were correlated with other influential variables through a multiple linear regression model. R software (R Core Team 2019) was used for model estimation. The estimation results are presented in Table 8.

Table 8. Model Estimation Results

\begin{tabular}{|c|c|c|c|c|c|}
\hline Variable & Coefficient & Std. Err & $\mathrm{t}$ & $\mathrm{p}$-value & Significance \\
\hline (Intercept) & 4.603 & 1.026 & 4.487 & $3.20 \mathrm{e}-05$ & $* * *$ \\
\hline Distance & 0.029 & 0.009 & 3.167 & 0.00239 & ** \\
\hline Pavement & 2.141 & 0.794 & 2.697 & 0.00900 & $* *$ \\
\hline Wspeed & 0.303 & 0.193 & 1.571 & 0.12117 & \\
\hline Paragon & 3.437 & 0.762 & 4.511 & $2.93 \mathrm{e}-05$ & $* * *$ \\
\hline Concrete & 2.773 & 1.001 & 2.770 & 0.00738 & $* *$ \\
\hline Traffic & 3.121 & 1.583 & 1.971 & 0.05316 & . \\
\hline Pavement*Traffic & -5.037 & 1.800 & -2.798 & 0.00684 & $* *$ \\
\hline \multicolumn{6}{|c|}{ F-statistic $=6.561$} \\
\hline
\end{tabular}

Note: significance level: $* * * 0.001, * * 0.01, * 0.05, \cdot 0.10$.

It should be pointed out that given the dummy variable coding, the interlocking steel barrier type was excluded from the model specification because it was used as the reference base for assessing noise reduction effects of the other two barrier types. The effect leverage plot, showing the unique effect of any particular term in the model, is presented in Figure 6. 


\section{Leverage Plots}
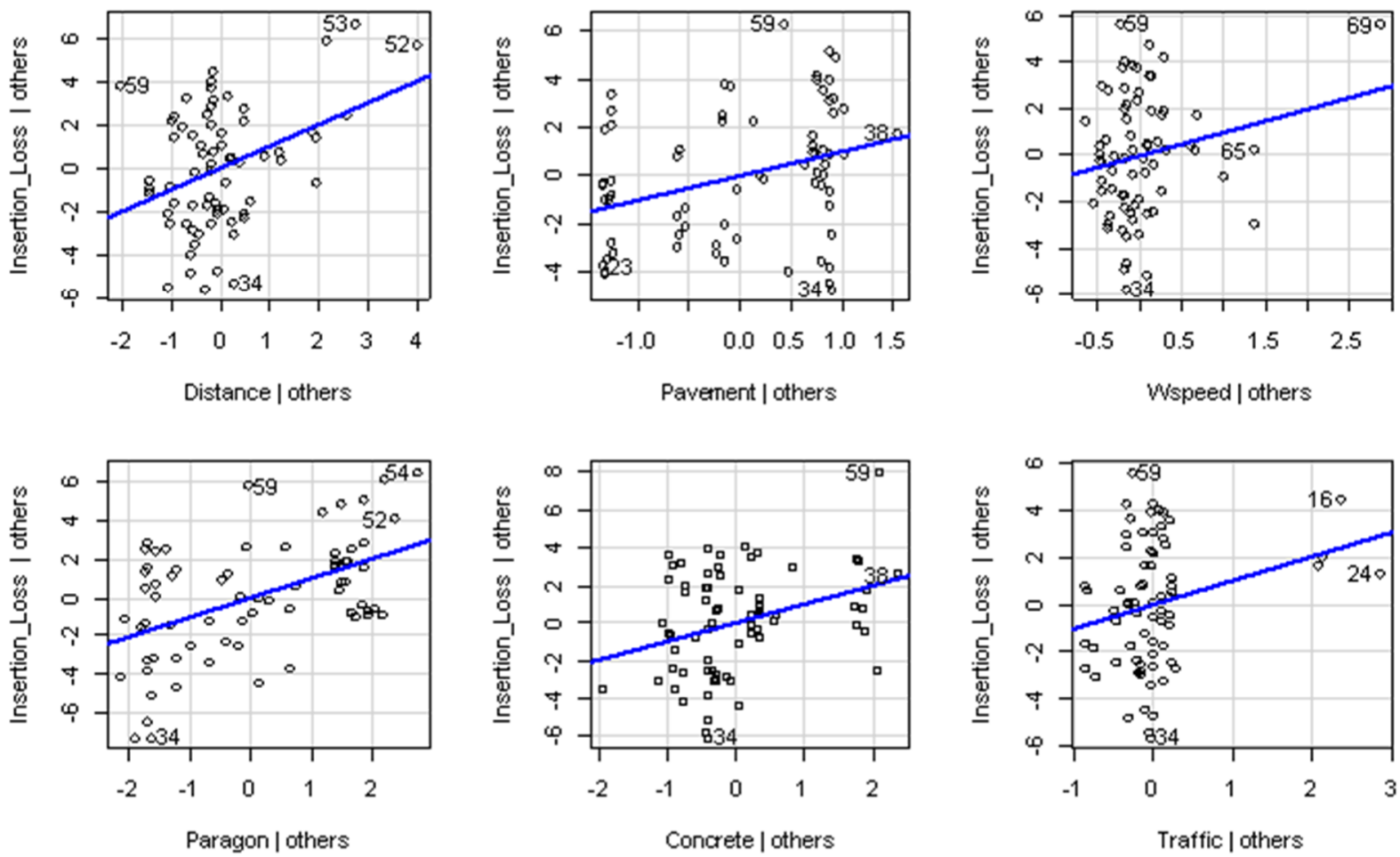

Figure 6. Effect Leverage Plot 
To verify the normality assumption for the models estimated in Table 8, quantile-quantile (Q-Q) plot and standardized residuals distribution are shown in Figure 7.
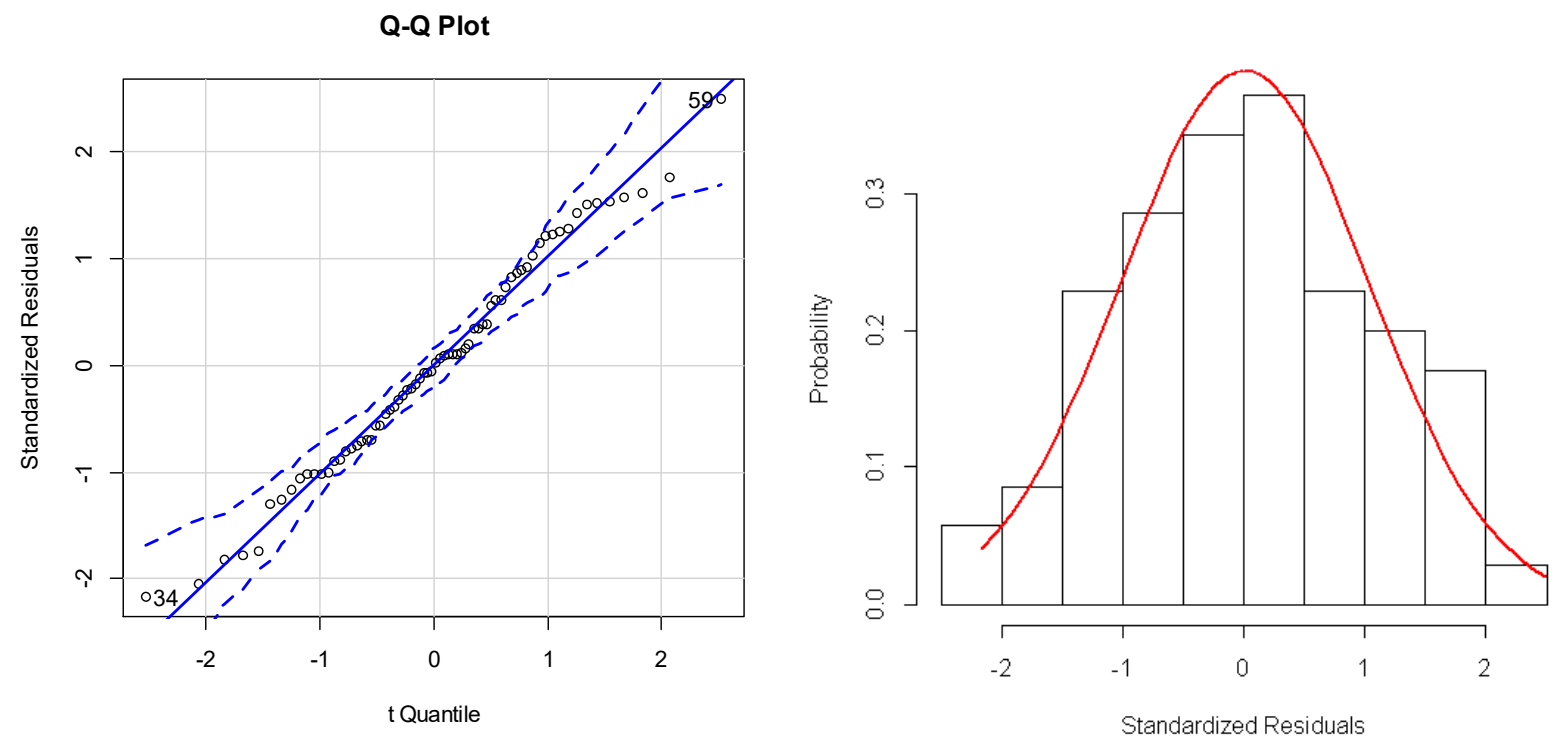

Figure 7. Q-Q Plot and Distribution of Standardized Residuals.

As seen in Figure 7, the residual histogram aligns well with the corresponding normal distribution curve. The Q-Q plot indicates an approximate normality as the residual data points closely follow the straight line within the confidence band. The model estimation results in Table 8 showed that all variables are significant at the 0.01 level except for the wind speed and traffic condition. Traffic condition is close to $5 \%$ significant level and the wind speed is close to 10\% significance level. The positive coefficient sign of the Distance variable indicates an increasing insertion loss as the noise barrier is farther away from the traffic. Noting the interaction term between pavement type and traffic condition is significant at the 0.01 level and has a negative sign, explanation of the effect of one variable needs to consider the other variable. 
On concrete pavement, heavier traffic would contribute to a higher insertion loss as indicated by the positive coefficient for the Traffic variable. This is likely due to the fact that traffic noise on concrete pavement is sensitive to the vehicle speed, which was reduced because of the heavier traffic flow, resulting in a higher insertion loss. On asphalt pavement, lighter traffic will contribute to a positive insertion loss. However, heavier traffic on asphalt pavement would contribute marginal insertion loss because of the larger negative coefficient of the interaction term (i.e., -5.037). In fact, it nearly cancels the positive insertion loss from each individual variable (i.e., 2.141 for pavement type and 3.121 for traffic condition).

The positive coefficient for wind speed implies a higher insertion loss with a higher wind speed. Both concrete and Paragon panel 23-T barriers have a higher insertion loss as compared to the steel barrier as implied by the positive coefficients. The larger magnitude of coefficient for the Paragon panel 23-T barrier indicates a larger insertion loss than the concrete barrier (i.e., 3.437 versus 2.773$)$.

For parametric analysis, the model was applied by setting Distance $=72.5$ feet and Wspeed $=1.0$ miles per hour. The insertion losses of the three types of noise barriers were computed and plotted in Figure 8. 


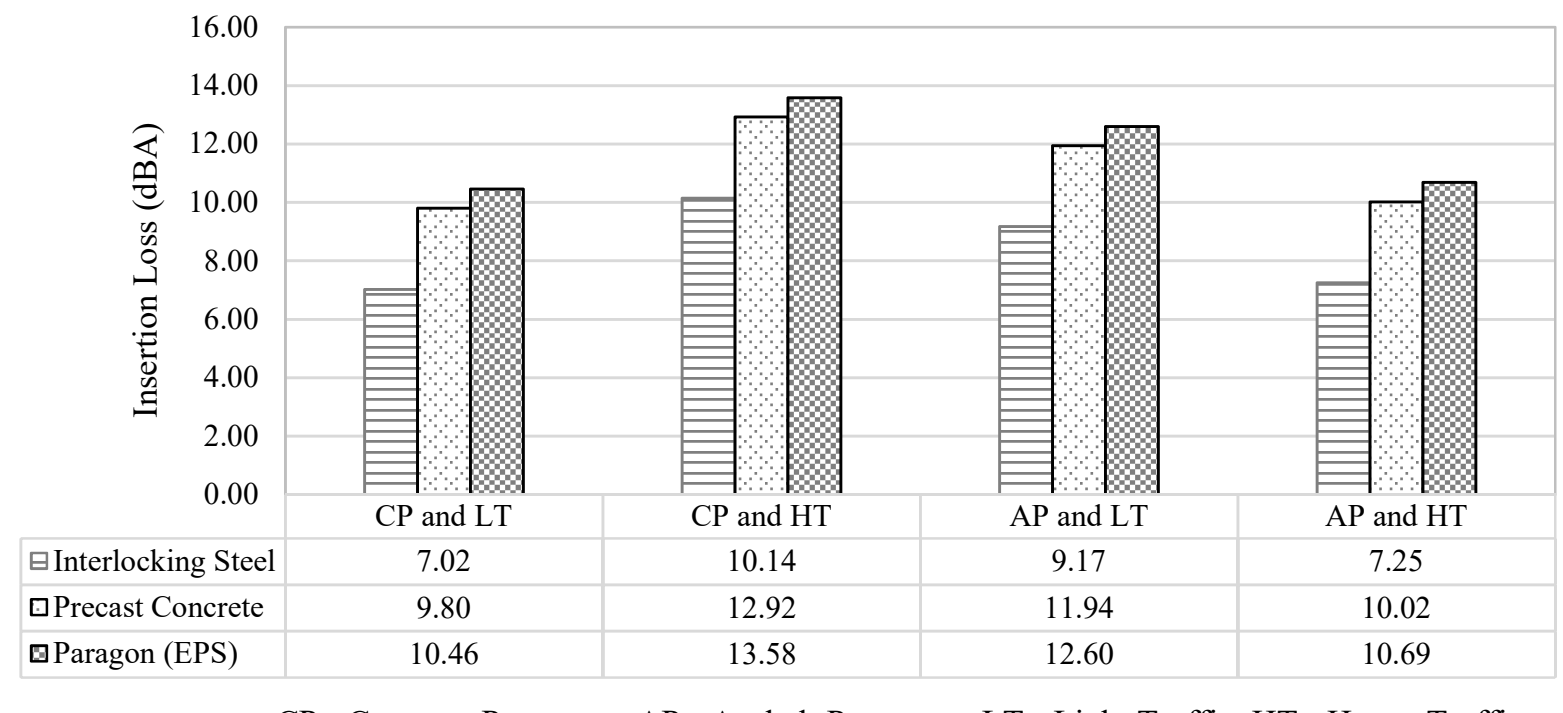

CP - Concrete Pavement; AP - Asphalt Pavement; LT - Light Traffic; HT - Heavy Traffic

Figure 8. Comparison of Insertion Loss of Traffic Noise Barriers.

As shown in Figure 8, Paragon panel 23-T barrier effects highest insertion loss, followed by precast concrete panel barrier and interlocking steel panel barrier. The highest insertion loss was achieved on concrete pavement when traffic is heavy. 


\section{CHAPTER 5: MULTI-CRITERIA ANALYSIS}

\section{Section 5.1 - Background \& Data}

The FHWA has reported that as of the end of 2004, more than 3,500 kilometers of barriers had been constructed in 45 states and the Commonwealth of Puerto Rico at a cost of more than $\$ 2.6$ billion (National Academy of Engineering 2010). Transportation Research Board's updated metrics states that approximately 4,829 kilometers of noise barriers have been constructed along U.S. highways to date, at an average cost of \$2 million per 1.6 kilometer of wall (\$6 million in 2018 dollars) (Transportation Research Board, 2018).

The multi-criteria evaluation method includes the analysis of more than one criterion at the same time. As support in the decision-making process, this method has been in use for a number of years in different fields of civil engineering (water management, construction management, road building, etc.). Today it is being increasingly used in the field of transport planning and designing. Sinisa, et al. (2018). Having defined the adequate attributes of each alternative by applying weighing coefficients to each variable, the evaluation of alternatives for the multi-criteria analysis has been done.

The multi-criteria analysis presented in this research includes three aspects and evaluates the most feasible noise barrier panel material for future noise barrier selection. The variables include: (1) noise insertion loss values obtained from field samples as described in Chapter 3 Section 3.2 of this paper, (2) a questionnaire on the constructability of the noise barriers in GDOT's Northwest Express project classifying either easy or difficult as shown in Fig. 9-10, (3) the cost incurred to construct the noise barriers was provided by the contractor. 
How would you rate the level of constructability for the traffic noise barrier with Interlocking Steel Panels (ShadowRib)?

8 responses

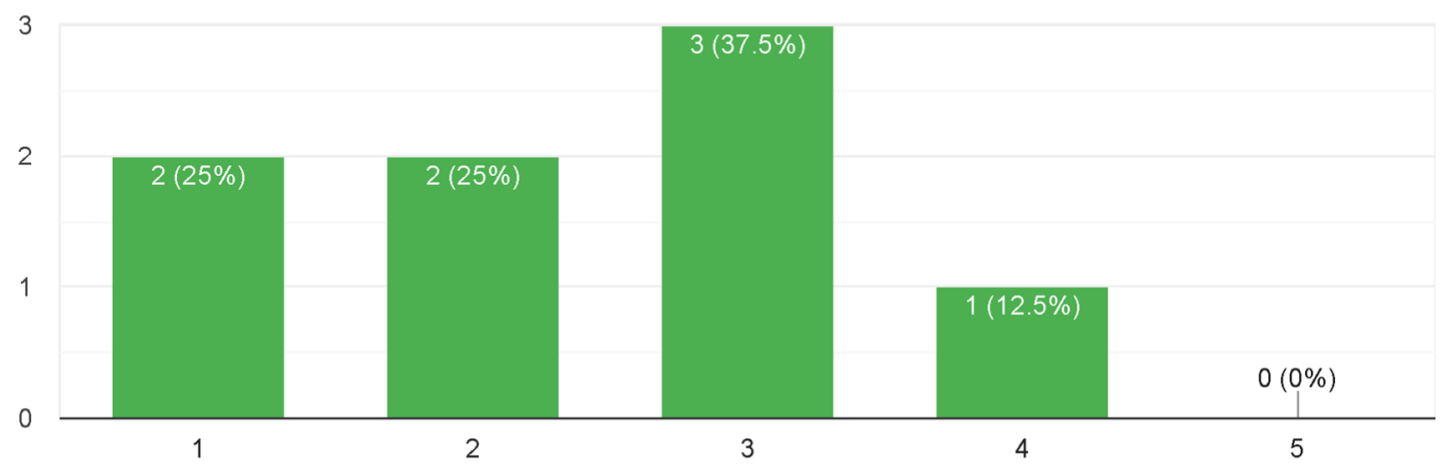

Figure 9. Interlocking Steel Panels Survey

How would you rate the level of constructability for the traffic noise barrier with Precast Concrete Panels (Duratek Wall Systems)?

8 responses

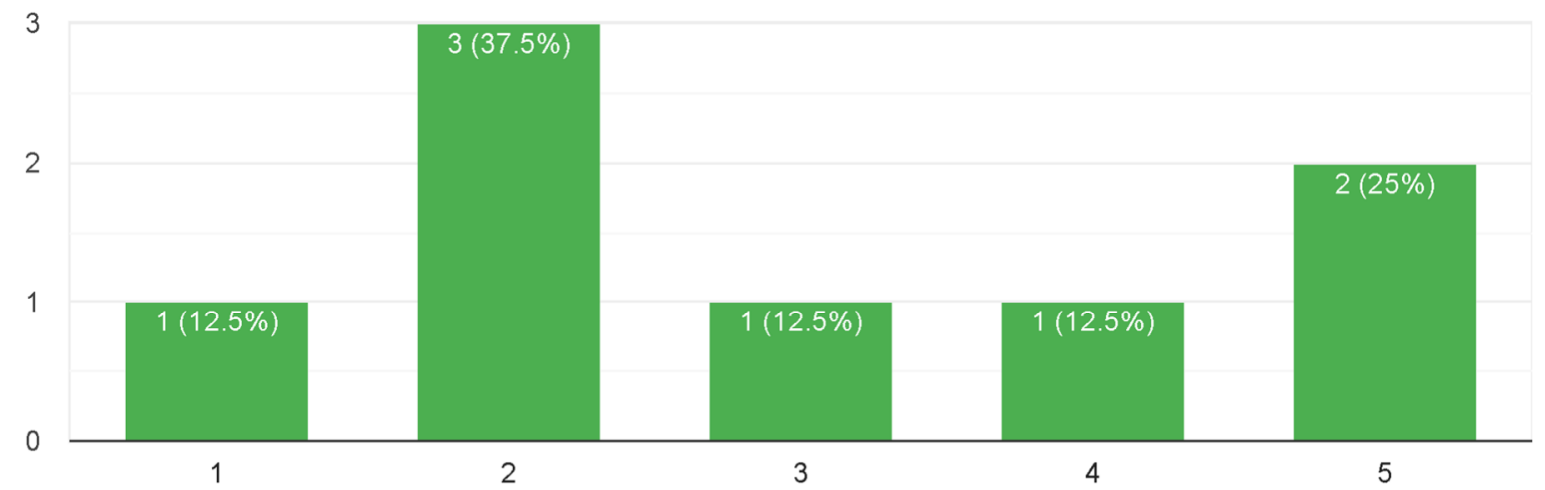

Figure 10. Precast Concrete Panels Survey 


\section{How would you rate the level of constructability for the traffic noise barrier with Styrofoam Panels (Noise D-Fence Paragon)? \\ 8 responses}

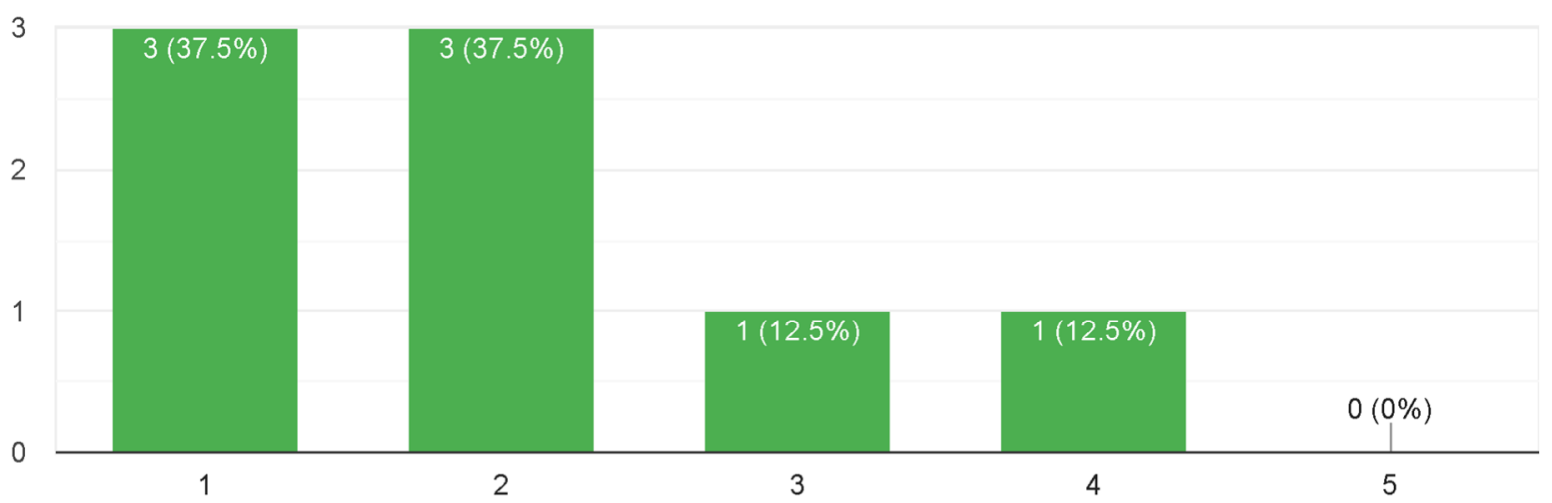

Figure 11. Paragon Panel 23-T Survey

Insertion loss values from each panel material (i.e., steel, concrete, Paragon panel 23-T) obtained from field samples were averaged and presented in Table 9. The questionnaire was presented to 14 engineers that were part of the team managing the construction of noise barriers on GDOT's Northwest Express project containing three questions. Eight of the 14 engineers provided feedback classifying whether they thought the three types of noise barriers (i.e., steel, concrete, and Paragon panel 23-T) were difficult or easy to construct, giving each barrier a rating of one through five. One being easy and five representing difficult. In addition to the noise insertion loss values and questionnaire, the cost incurred to build the Paragon panel 23-T noise barriers was provided by the contractor. The cost for steel and concrete panels were selected from the online bidding platform Bid Express (www.bidx.com). Once a proposal deadline has passed and the bids for projects have been opened, the bid tabulations for the proposal the contractor turned in is available to the public. The tabulations show what each contractor bid for 
each item and the overall bid total. The costs for each item in the bid tabulations include labor and materials for the entire noise barrier scope of work on projects in the State of Georgia. Table 9 shows the variables used to generate the multi-criteria analysis.

Table 9. Multi-criteria Analysis Variables.

\begin{tabular}{llll}
\hline Material & $\begin{array}{l}\text { Avg. Noise Reduction } \\
(\mathrm{dBA})\end{array}$ & $\begin{array}{l}\text { Constructability } \\
(\text { Rating } 1-5)\end{array}$ & $\begin{array}{l}\text { Cost } \\
(\$ / \mathrm{SF})\end{array}$ \\
\hline Steel & 8.14 & 2.375 & $\$ 24.46$ \\
Concrete & 11.19 & 3 & $\$ 37.02$ \\
Paragon & 11.44 & 2 & $\$ 21.40$ \\
\hline
\end{tabular}

Section 5.2 - Analysis and Results

Study of Nose Barrier Life-Cycle Costing research by Morgan, et al. (2001) presents the service life of noise barrier materials.

Table 10. Service Life of Noise Barriers (Morgan, et al., 2001)

\begin{tabular}{lccc}
\hline \hline & \multicolumn{3}{c}{ Service Life (years) by Literature Source } \\
\cline { 2 - 4 } Material & $\begin{array}{c}\text { Flodine } \\
(1991)\end{array}$ & $\begin{array}{c}\text { Bowlby } \\
(1992)\end{array}$ & $\begin{array}{c}\text { Lin et al. } \\
(1997)\end{array}$ \\
\hline Concrete & 40 & $45-50$ & $20-100$ \\
Masonry & 40 & - & - \\
Metal & - & - & 20 \\
$\quad$ Aluminum panels & 40 & - & - \\
$\quad$ Steel panels & 30 & - & - \\
Plastic & 25 & - & - \\
Wood & 15 & $20-50$ & $30-50$ \\
Proprictary-Durisol & 40 & - & - \\
\hline \hline
\end{tabular}


The service life values of concrete and steel panels incorporated in the multi-criteria analysis were used from Morgan's, et al. (2001) research. The service life of Paragon panel 23-T presented to the GDOT by Paragon Noise Barriers, Inc. is 100 years (Paragon Noise Barriers, 2017). Based on the performance experienced at GDOT's Northwest Express project from Paragon panel 23-T noise barriers, an assumption of 15 years life cycle was made for this analysis. A 3\% interest rate accounting for inflation was also used in the evaluation and an Equivalent Uniform Annual Cost (EUAC) was generated for each noise barrier.

Table 11. Equivalent Uniform Annual Cost (EUAC)

\begin{tabular}{|c|c|c|c|c|c|c|c|}
\hline & Steel & Concrete & Paragon panel 23-T & & Steel & Concrete & Paragon panel 23-T \\
\hline Service life & 25 & 50 & 15 & & $\mathrm{PV}$ & $\mathrm{PV}$ & $\mathrm{PV}$ \\
\hline Initial cost & $\$ 7,338,000.00$ & $\$ 11,106,000.00$ & $\$ 6,420,000.00$ & & $\$ 7,338,000.00$ & $\$ 11,106,000.00$ & $\$ 6,420,000.00$ \\
\hline Annual maintenance cost & $\$ 15,900.00$ & $\$ 12,300.00$ & $\$ 13,800.00$ & & $\$ 276,869.05$ & $\$ 316,476.10$ & $\$ 164,743.50$ \\
\hline \multirow[t]{2}{*}{ Salvage value } & $\$ 0.00$ & $\$ 0.00$ & $\$ 0.00$ & & $\$ 0.00$ & $\$ 0.00$ & $\$ 0.00$ \\
\hline & & & & $\mathrm{PV}$ & $\$ 7,614,869.05$ & $\$ 11,422,476.10$ & $\$ 6,584,743.50$ \\
\hline \multirow[t]{2}{*}{ Interest rate: } & $3 \%$ & & & & & & \\
\hline & & & & EUAC & $\$ 437,305.72$ & $\$ 443,940.18$ & $\$ 551,581.45$ \\
\hline
\end{tabular}

Table 11 shows the criteria evaluated to generate the EUAC for the life cycle of the noise barriers. The life cycle cost for each noise barrier (i.e., concrete, steel, Paragon panel 23-T) was generated using the same approach evaluated in Morgan's, et al. (2001) research. Figure 10 represents the life cycle cost of each type of noise barrier. $\mathrm{ICC}=$ Initial construction cost, $\mathrm{G}=$ Graffiti removal $1 \%$ of barrier surface area, $P R=$ Barrier painting, $1 \%$ of barrier surface area, $D$ $=$ disposal. 


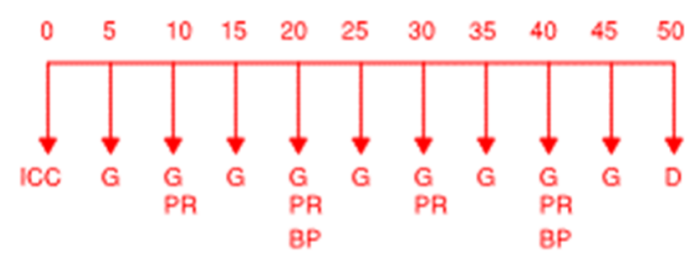

a) Precast Concrete Panel

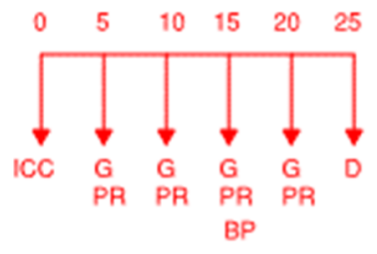

b) Interlocking Steel Panel

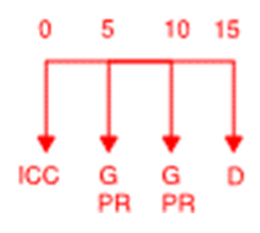

c) Paragon panel 23-T

Figure 12. Life Cycle of Noise Barriers

Once the multi-criteria analysis was performed using the values from this research, based on noise reduction, EUAC, and constructability, the final score for each barrier is steel $=51.31$, concrete $=57.12$, Paragon panel 23- $\mathrm{T}=65.71$. A value of 65.71 represents the best performing noise barrier panel material that should be considered in future projects containing noise barriers. Table 12 shows a summary of each criteria, weight, and type of wall.

Table 12. Multi-Criteria Summary

\begin{tabular}{|c|c|c|c|c|}
\hline \multirow[b]{2}{*}{ Criteria } & \multirow[b]{2}{*}{ Weight } & \multicolumn{3}{|c|}{ Type of wall } \\
\hline & & Steel & Concrete & Paragon panel 23-T \\
\hline \multicolumn{5}{|l|}{ Noise } \\
\hline Reduction & 0.40 & 31.40 & 61.90 & 64.38 \\
\hline EUAC & 0.20 & 62.52 & 61.78 & 49.82 \\
\hline Constructability & 0.40 & 65.63 & 50.00 & 75.00 \\
\hline & $\begin{array}{l}\text { Final } \\
\text { Score }\end{array}$ & 51.31 & 57.12 & 65.71 \\
\hline
\end{tabular}




\section{CHAPTER 6: CONCLUSIONS}

\section{Section 6.1 - Conclusions}

In this study, the insertion loss of traffic noise barriers was evaluated based on the field data collected along the recently completed Northwest Express project in Georgia. Three types of noise barriers with different materials (i.e., steel, concrete, and Paragon panel 23-T) were installed as part of the project for noise abatement. To evaluate the effectiveness of different noise barriers, multiple linear regression was performed to control the variance due to other influential factors, including the distance of the barrier from traffic, pavement type, traffic conditions, and wind speed. Those site-related factors could be considered as part of noise barrier selection and installation process for effective noise abatement. The results showed that under prevailing conditions, controlled by other influential variables, all three types of noise barriers, i.e., interlocking steel panels, precast concrete panels, and Paragon panel 23-T, resulted in an insertion loss that exceed the noise reduction design goal of $7 \mathrm{dBA}$ as stated in the GDOT noise Abatement policy. Paragon panel 23-T barriers effect the highest insertion loss, followed by precast concrete panel barriers and interlocking steel panel barriers. The highest insertion loss of $13.58 \mathrm{dBA}$ was achieved by the Paragon panel 23-T barrier on concrete pavement when traffic is heavy.

The FHWA (2011) defines a benefited receptor as a "recipient" of an abatement measure that receives a noise reduction at or above the minimum threshold of $5 \mathrm{dBA}$, but not to exceed the highway agency's reasonableness design goal. This study showed that the noise barriers 
installed as part of the Northwest Express project effect a noise reduction in the range of 7.02 $\mathrm{dBA}$ and $13.58 \mathrm{dBA}$, exceeding this minimum threshold of $5 \mathrm{dBA}$.

Multi-criteria evaluation has been applied. Three criteria have been considered, including insertion loss, constructability, and the life cycle cost. These aspects are normally considered by agencies for selecting the proper noise barrier for their highway projects. It showed that the Paragon panel 23-T noise barrier yielded the highest score.

Besides the noise reduction, other practical aspects of noise barriers should be evaluated as well, such as structural integrity and accurate annual maintenance costs. Low structural integrity leads to higher maintenance costs as panel replacements are more frequent. A further study is recommended to consider those additional aspects. Furthermore, the Fuzzy AHP framework may be considered to account for inherent uncertainty and imprecision associated with the mapping of the decision-maker's perception to exact numbers (Deng 1999). 


\section{REFERENCES}

1. Arenas, C., Leiva, C., Vilches, L. F., Cifuentes, H. (2013). "Use of co-combustion bottom ash to design an acoustic absorbing material for highway noise barriers." Waste Management., 33(11), 2316-2321.

2. Daee, B., \& El Naggar, M. (2015). "Short communication: Application of flexi-wall in noise barriers renewal." Case Studies in Construction Materials., 3: 48-55.

3. Debije, M. G., Tzikas, C., de Jong, M. M., Kanellis, M., \& Slooff, L. H. (2018). “The solar noise barrier project: 3 . The effects of seasonal spectral variation, cloud cover and heat distribution on the performance of full-scale luminescent solar concentrator panels." Renewable Energy., 116 Part A:335-343.

4. del Rey, R., Berto, L., Alba, J., \& Arenas, J. P. (2015). “Acoustic characterization of recycled textile materials used as core elements in noise barriers." Noise Control Engineering Journal., Vol 63/p439-447.

5. Federal Highway Administration. 2009d. Highway Noise Barrier Design Handbook. Available online at $<\mathrm{http}: / /$ hwwa.dot.gov/environmental/noise/design/index.htm. $>$

6. Federal Highway Administration. (2017). Highway Traffic Noise, Washington, D.C.

7. Federal Highway Administration. (1996). Measurement of Highway-Related Noise, Cambridge, MA

8. Federal Highway Administration (2011). "Procedures for Abatement of Highway Traffic Noise and Construction Noise." <https://www.gpo.gov/fdsys/pkg/FR-2010-0713/pdf/2010-15848.pdf $>$ (Nov. 2018)

9. Federal Highway Administration. (2017). Traffic Noise Model, Washington, D.C. 
10. GDOT (Georgia Department of Transportation). (2016). Highway Noise Abatement Policy for Federal-Aid Projects., Atlanta, GA.

11. Gil-Lopez, T., Medina-Molina, M., Verdu-Vazquez, A., \& Martel-Rodriguez, B. (2017). "Acoustic and economic analysis of the use of palm tree pruning waste in noise barriers to mitigate the environmental impact of motorways." Science Of The Total Environment., 584-585.

12. Harris, R.A., Cohn, L.F. (2000). "Evaluation of the Federal Highway Administration's traffic noise model.” Journal of Transportation Engineering., 513-520.

13. Ingunn M., Sigve J. A., Kjell S. (2012). "Value for money in road traffic noise abatement." Procedia - Social and Behavioral Sciences., Volume 48/1366-1374.

14. Kim, K. H., \& Yoon, G. H. (2015). "Optimal rigid and porous material distributions for noise barrier by acoustic topology optimization." Journal of Sound and Vibration., 339: $123-142$

15. Kumar, K., Parida, M., \& Katiyar, V. (2014). “Optimized height of noise barrier for nonurban highway using artificial neural network.” International Journal Of Environmental Science \& Technology. Vol. 11/719-730.

16. Lacasta, A., Penaranda, A., Cantalapiedra, I., Auguet, C., Bures, S., \& Urrestarazu, M. (2016). “Acoustic evaluation of modular greenery noise barriers.” Urban Forestry \& Urban Greening., 20:172-179.

17. Metal Building Components, L.P. "Concealed fastening metal panel used for walls, fascias and equipment screens." $<$ http://www.mbci.com/products/wall/concealedfastening-wall-systems/shadowrib-/> (Mar. 2017) 
18. National Academy of Engineering (2010). Technology for a Quieter America, National Academies Press, Washington, D.C.

19. Old Castle Precast. "Duratek Walls." $<$ https://oldcastleprecast.com/duratek-walls/> (Mar. 2017).

20. Petrovici, A. M., Cueto, J. L., Gey, R., Nedeff, F., Hernandez, R., Tomozei, C., Mosnegutu, E. (2016). "Optimization of some alternatives to noise barriers as noise mitigation measures on major roads in Europe. Case study of a highway in Spain.” Environmental Engineering \& Management Journal., Vol. 15, Issue 7, 1617-1628.

21. R Core Team (2019). R: A language and environment for statistical computing. R Foundation for Statistical Computing, Vienna, Austria. URL https://www.R-project.org/.

22. Reiter, P., Wehr, R., \& Ziegelwanger, H. (2017). "Simulation and Measurement of Noise Barrier Sound-Reflection Properties.” Applied Acoustics., 123:133-142.

23. Seong J.C., Tae H. Park, Joon H. Ko, Seo I. Chang, Minho Kim, James B. Holt, Mohammed R. Mehdi. (2011). "Modeling of road traffic noise and estimated human exposure in Fulton County, Georgia, USA.” Environmental International., Vol. 37, Issue $8,1336-1341$

24. Surahyo M., El-Diraby T.E. (2009). "Schema for Interoperable Representation of Environmental and Social Costs in Highway Construction.” Journal of Const. Eng. \& Management., Vol. 135/254-266.

25. Susan M. Morgan., Dianne H. Kay., S. Narayan Bodapati. (2001). "Study of Noise Barrier Life-Cycle Costing.” Journal of Transportation Engineering., Vol. 127/230. 
26. Toledo, R., Aznárez, J., Greiner, D., \& Maeso, O. (2017). “A methodology for the multiobjective shape optimization of thin noise barriers." Applied Mathematical Modelling., 50:656-675.

27. Transportation Research Board. (2018). "Breaking Barriers: Alternative Approaches to Avoiding and Reducing Highway Traffic Noise Impacts.” http://rid.trb.org/Results?txtKeywords=noise+barriers+maintenance+cost\#/View/151618 6 (Mar. 10, 2019).

28. World Health Organization Book. (2011). WHO Regional Office for Europe, Copenhagen.

29. Weather Underground (2018). Historical Weather - Marietta, Georgia <https://www.wunderground.com/history/daily/us/ga/marietta/KATL/date/2018-7-24> (Nov. 2018)

30. Vilke Sinisa., Krpan Ljudevit., Marin Milkovic. (2018) “Application of the Multi-Criteria Analysis in the Process of Road Route Evaluation.” Tehnicki Vjesnik - Technical Gazette., Vol. 25/1851.

Deng, H, (1999). “Multicriteria analysis with fuzzy pairwise comparisons”. International Journal of Approximate Reasoning. Vol. 21, pp. 215-231. 


\section{APPENDIX A}

Data

\begin{tabular}{|c|c|c|c|c|c|c|c|c|c|c|c|c|c|c|c|}
\hline Location & $\begin{array}{l}\text { Wall_H } \\
\text { eight }\end{array}$ & $\begin{array}{l}\text { Dista } \\
\text { nce }\end{array}$ & $\begin{array}{l}\text { Pave } \\
\text { ment }\end{array}$ & $\begin{array}{l}\text { Wsp } \\
\text { eed }\end{array}$ & $\begin{array}{l}\text { Styrof } \\
\text { oam }\end{array}$ & $\begin{array}{l}\text { Conc } \\
\text { rete }\end{array}$ & $\begin{array}{l}\text { Tra } \\
\text { ffic }\end{array}$ & $\begin{array}{l}\text { Te } \\
\mathrm{mp} \\
79 .\end{array}$ & $\begin{array}{l}\text { De } \\
\text { w }\end{array}$ & $\begin{array}{l}\text { Humi } \\
\text { dity }\end{array}$ & $\begin{array}{l}\text { Press } \\
\text { ure } \\
28.9\end{array}$ & $\begin{array}{l}\text { Precip } \\
\text { _Rate }\end{array}$ & $\begin{array}{l}\text { Precip_ } \\
\text { Accum }\end{array}$ & $\begin{array}{r}\text { Delta } \\
\text { _dBA }\end{array}$ & $\begin{array}{l}\text { Insertio } \\
\text { n_Loss }\end{array}$ \\
\hline Wall_8C_Bay6 & 27.75 & 84 & 0 & 1 & 1 & 0 & 0 & $\begin{array}{r}4 \\
89 .\end{array}$ & 68 & 69 & $\begin{array}{r}3 \\
29.0\end{array}$ & 0 & 0 & 11.5 & 8.65 \\
\hline Wall_8C_Bay3_1 & 26 & 82 & 0 & 0 & 1 & 0 & 0 & $\begin{array}{r}8 \\
92 .\end{array}$ & 70 & 53 & $\begin{array}{r}6 \\
28.9\end{array}$ & 0 & 0 & 7.7 & 7.65 \\
\hline Wall_8C_Bay3_2 & 26 & 82 & 0 & 0 & 1 & 0 & 0 & 5 & 71 & 50 & $\begin{array}{r}5 \\
29.0\end{array}$ & 0 & 0 & 9.2 & 7.8 \\
\hline Wall_8A_Bay27 & 28.82 & 64 & 0 & 2 & 0 & 1 & 0 & $\begin{array}{r}89 \\
89 .\end{array}$ & 70 & 55 & $\begin{array}{r}4 \\
29.0\end{array}$ & 0 & 0 & 12.9 & 11.3 \\
\hline Wall_8A_Bay24 & 29 & 58 & 0 & 1 & 1 & 0 & 0 & $\begin{array}{r}6 \\
80 .\end{array}$ & 70 & 54 & $\begin{array}{r}3 \\
28.9\end{array}$ & 0 & 0 & 13.6 & 10.95 \\
\hline Wall_9A_Bay30 & 34.25 & 70 & 0 & 1 & 1 & 0 & 0 & $\begin{array}{r}1 \\
79 .\end{array}$ & 68 & 68 & $\begin{array}{r}5 \\
28.9\end{array}$ & 0 & 0 & 9 & 7.7 \\
\hline Wall_9A_Bay8 & 31.82 & 75 & 0 & 2 & 0 & 1 & 0 & $\begin{array}{r}6 \\
80 .\end{array}$ & 68 & 69 & $\begin{array}{r}4 \\
28.9\end{array}$ & 0 & 0 & 9.4 & 8.35 \\
\hline Wall_9A_Bay2 & 17 & 70 & 0 & 0 & 1 & 0 & 0 & $\begin{array}{r}5 \\
80 .\end{array}$ & 70 & 71 & $\begin{array}{r}8 \\
28.9\end{array}$ & 0 & 0.14 & 13.8 & 13.3 \\
\hline $\begin{array}{l}\text { Wall_9A_Bay9 } \\
\text { Wall_9A_Bay60_ }\end{array}$ & 31.82 & 76 & 0 & 0 & 0 & 1 & 0 & 5 & 71 & 73 & $\begin{array}{r}9 \\
29.0\end{array}$ & 0 & 0.14 & 10.8 & 8.5 \\
\hline $\begin{array}{l}1 \\
\text { Wall_9A_Bay36_ }\end{array}$ & 17.67 & 68 & 0 & 0 & 0 & 0 & 0 & $\begin{array}{r}90 \\
90 .\end{array}$ & 70 & 53 & $\begin{array}{r}4 \\
29.0\end{array}$ & 0 & 0 & 4.8 & 5.1 \\
\hline $\begin{array}{l}1 \\
\text { Wall_9A_Bay60_ }\end{array}$ & 17.67 & 70 & 0 & 1 & 0 & 0 & 0 & 3 & 70 & 53 & $\begin{array}{r}3 \\
28.9\end{array}$ & 0 & 0 & 8.9 & 10.25 \\
\hline 2 & 17.67 & 68 & 0 & 1 & 0 & 0 & 0 & $\begin{array}{c}76 \\
76 .\end{array}$ & 71 & 85 & $\begin{array}{r}3 \\
28.9\end{array}$ & 0 & 0 & 5.5 & 7.3 \\
\hline 2 & 17.67 & 70 & 0 & 1 & 0 & 0 & 0 & 3 & 71 & 85 & 4 & 0 & 0 & 11.4 & 11.55 \\
\hline
\end{tabular}




\begin{tabular}{|c|c|c|c|c|c|c|c|c|c|c|c|c|c|c|c|}
\hline Wall_9A_Bay60_ & & & & & & & & 93. & & & 28.9 & & & & \\
\hline 3 & 17.67 & 68 & 0 & 4 & 0 & 0 & 0 & 5 & 72 & 50 & 6 & 0 & 0 & 5.1 & 5.85 \\
\hline Wall_9A_Bay36_ & & & & & & & & & & & 28.9 & & & & \\
\hline 3 & 17.67 & 70 & 0 & 0 & 0 & 0 & 0 & 93 & 71 & 50 & 6 & 0 & 0 & 11.4 & 10.6 \\
\hline Wall_9C_Bay15_ & & & & & & & & 80. & & & & & & & \\
\hline 1 & 36 & 79 & 0 & 0 & 0 & 1 & 1 & 1 & 69 & 69 & 28.9 & 0 & 0 & 16.7 & 14.9 \\
\hline Wall_9C_Bay15_ & & & & & & & & 81. & & & 28.9 & & & & \\
\hline 2 & 36 & 79 & 0 & 2 & 0 & 1 & 0 & 4 & 71 & 70 & 9 & 0 & 0.14 & 12.5 & 11.9 \\
\hline & & & & & & & & 78. & & & 28.8 & & & & \\
\hline Wall_9D_Bay13 & 18 & 101 & 0 & 4 & 0 & 1 & 1 & 8 & 69 & 71 & 9 & 0 & 0 & 14.3 & 14.5 \\
\hline & & & & & & & & 78. & & & 28.8 & & & & \\
\hline Wall_9D_Bay27 & 23.5 & 128 & 0 & 4 & 0 & 1 & 1 & 8 & 69 & 71 & 9 & 0 & 0 & 13.8 & 15.05 \\
\hline Wall_10/11A_Ba & & & & & & & & 70. & & & 28.9 & & & & \\
\hline y55_1 & 22.08 & 66 & 0 & 2 & 1 & 0 & 0 & 5 & 66 & 86 & 7 & 0 & 0 & 12.6 & 10.9 \\
\hline Wall_10/11A_Ba & & & & & & & & 79. & & & 28.9 & & & & \\
\hline y59 & 22.5 & 64 & 0 & 0 & 0 & 1 & 0 & 9 & 71 & 75 & 8 & 0 & 0.14 & 9.1 & 6.95 \\
\hline Wall_10/11A_Ba & & & & & & & & 80. & & & 28.9 & & & & \\
\hline y55_2 & 22.08 & 66 & 0 & 0 & 1 & 0 & 0 & 3 & 70 & 71 & 9 & 0 & 0.14 & 11.3 & 11 \\
\hline Wall_10/11A_Ba & & & & & & & & 89. & & & 29.1 & & & & \\
\hline y101 & 20.92 & 56 & 0 & 1 & 1 & 0 & 0 & 6 & 64 & 44 & 2 & 0 & 0 & 8.5 & 7.6 \\
\hline Wall_10/11A_Ba & & & & & & & & 76. & & & 29.0 & & & & \\
\hline y1_1 & 17.67 & 57 & 0 & 0 & 0 & 0 & 1 & 8 & 70 & 81 & 3 & 0 & 0 & 7.4 & 7.85 \\
\hline Wall_10/11A_Ba & & & & & & & & 76. & & & 28.9 & & & & \\
\hline y1_2 & 17.67 & 57 & 0 & 3 & 0 & 0 & 0 & 4 & 71 & 85 & 4 & 0 & 0 & 5.7 & 8.2 \\
\hline Wall_10/11A_Ba & & & & & & & & 93. & & & 28.9 & & & & \\
\hline y1_3 & 17.67 & 57 & 0 & 1 & 0 & 0 & 0 & 5 & 72 & 50 & 7 & 0 & 0 & 6.1 & 6.85 \\
\hline Wall_10/11B_Ba & & & & & & & & 89. & & & 29.1 & & & & \\
\hline y13 & 18.5 & 123 & 0 & 1 & 0 & 1 & 0 & 6 & 64 & 44 & 2 & 0 & 0 & 12 & 10.45 \\
\hline & & & & & & & & 72. & 67 & & & & & & \\
\hline Wall_14_Bay10 & 33.75 & 62 & 1 & 1 & 1 & 0 & 1 & 2 & .1 & 84 & 29.8 & 0 & 0 & 11.6 & 7.75 \\
\hline & & & & & & & & 85. & 66 & & 30.1 & & & & \\
\hline Wall_14_Bay6 & 33.92 & 65 & 1 & 1 & 1 & 0 & 0 & 8 & .7 & 53 & 4 & 0 & 0 & 14.8 & 12.65 \\
\hline Wall_14_Bay18_ & & & & & & & & 85. & & & 30.1 & & & & \\
\hline 1 & 17.67 & 65 & 1 & 0 & 0 & 0 & 0 & 8 & 68 & 55 & 5 & 0 & 0 & 12.7 & 11.7 \\
\hline
\end{tabular}




\begin{tabular}{|c|c|c|c|c|c|c|c|c|c|c|c|c|c|c|c|}
\hline Wall_14_Bay18_ & & & & & & & & & 73 & & 29.9 & & & & \\
\hline $2--7$ & 17.67 & 65 & 1 & 0 & 0 & 0 & 0 & 75 & .1 & 94 & 6 & 0 & 0 & 8.7 & 8.7 \\
\hline Wall_14_Bay18_ & & & & & & & & 88. & 73 & & 29.9 & & & & \\
\hline $3--1-$ & 17.67 & 65 & 1 & 0 & 0 & 0 & 0 & 8 & .4 & 60 & 9 & 0 & 0 & 14.4 & 12.9 \\
\hline Wall_15_Bay16_ & & & & & & & & 75. & 73 & & 29.9 & & & & \\
\hline $1--1-$ & 17.67 & 81 & 1 & 0 & 0 & 0 & 0 & 1 & .2 & 94 & 6 & 0 & 0 & 5.5 & 5.75 \\
\hline Wall_15_Bay16_ & & & & & & & & 88. & 72 & & 29.9 & & & & \\
\hline 2 & 17.67 & 81 & 1 & 0 & 0 & 0 & 0 & 1 & .8 & 60 & 7 & 0 & 0 & 3.3 & 3.5 \\
\hline Wall_16_Bay52_ & & & & & & & & 76. & 75 & & 29.9 & & & & \\
\hline 1 & 13.92 & 68 & 1 & 0 & 0 & 0 & 1 & 6 & .4 & 96 & 7 & 0 & 0 & 2.3 & 4.95 \\
\hline Wall_16_Bay52_ & & & & & & & & 75. & 73 & & 29.9 & & & & \\
\hline 2 & 13.92 & 68 & 1 & 0 & 0 & 0 & 0 & 4 & .2 & 93 & 6 & 0 & 0 & 6.9 & 7.2 \\
\hline Wall_19_EndofW & & & & & & & & 72. & 69 & & 28.8 & & & & \\
\hline ylieRd & 10 & 91 & 1 & 0 & 1 & 0 & 0 & 7 & .9 & 91 & 6 & 0 & 0.01 & 13 & 12.5 \\
\hline Wall_19_Infront & & & & & & & & 72. & 70 & & 28.8 & & & & \\
\hline ofChurch & 10 & 86 & 1 & 0 & 0 & 1 & 0 & 7 & .6 & 93 & 6 & 0 & 0.01 & 12 & 12.25 \\
\hline Wall_19_Byroun & & & & & & & & 72. & 70 & & 28.8 & & & & \\
\hline dbuilding_1 & 11 & 89 & 1 & 0 & 0 & 0 & 0 & 5 & .7 & 94 & 6 & 0 & 0.01 & 11 & 11 \\
\hline Wall_19_Byroun & & & & & & & & 80. & 75 & & & & & & \\
\hline dbuilding_2 & 11 & 89 & 1 & 0 & 0 & 0 & 0 & $\begin{array}{r}4 \\
86 .\end{array}$ & .6 & 85 & 0 & 0 & 0.02 & 12.8 & 11.65 \\
\hline Wall_22_Bay1_1 & 17.67 & 59 & 1 & 1 & 0 & 0 & 0 & $\begin{array}{r}4 \\
71 .\end{array}$ & 77 & 74 & $\begin{array}{l}30.3 \\
30.4\end{array}$ & 0 & 0.01 & 2.1 & 3.45 \\
\hline Wall_22_Bay1_2 & 17.67 & 59 & 1 & 0 & 0 & 0 & 1 & $\begin{array}{r}4 \\
89 .\end{array}$ & 67 & 86 & $\begin{array}{r}5 \\
30.2\end{array}$ & 0 & 0 & 8 & 8.95 \\
\hline Wall_24_Bay5_1 & 13 & 61 & 1 & 1 & 1 & 0 & 0 & $\begin{array}{r}6 \\
68 .\end{array}$ & 76 & 65 & $\begin{array}{r}9 \\
30.2\end{array}$ & 0 & 0 & 11.1 & 11.5 \\
\hline Wall_24_Bay5_2 & 13 & 61 & 1 & 0 & 1 & 0 & 1 & $\begin{array}{r}9 \\
68 .\end{array}$ & 64 & 85 & 9 & 0 & 0.3 & 5.1 & 7.05 \\
\hline $\begin{array}{l}\text { Wall_24_Bay2 } \\
\text { Wall_24_Bay24_}\end{array}$ & 19.58 & 61 & 1 & 0 & 0 & 1 & 1 & $\begin{array}{r}9 \\
85 .\end{array}$ & 64 & 85 & 30.3 & 0 & 0.3 & 8.6 & 4.9 \\
\hline $1-$ & 17.67 & 70 & 1 & 0 & 0 & 0 & 0 & 7 & 76 & 75 & 30.3 & 0 & 0 & 3.8 & 4.1 \\
\hline Wall_24_Bay24_ & & & & & & & & 70. & & & 30.4 & & & & \\
\hline 2 & 17.67 & 70 & 1 & 0 & 0 & 0 & 1 & 6 & 66 & 86 & 5 & 0 & 0 & 3.5 & 3.5 \\
\hline
\end{tabular}




\begin{tabular}{|c|c|c|c|c|c|c|c|c|c|c|c|c|c|c|c|}
\hline Wall_24_Bay24_ & & & & & & & & 91. & & & & & & & \\
\hline $3-$ & 17.67 & 70 & 1 & 0 & 0 & 0 & 0 & 9 & 72 & 53 & 30.3 & 0 & 0 & 7.1 & 6.7 \\
\hline Wall_27/28_Bay & & & & & & & & 87. & & & & & & & \\
\hline 6 & 17.67 & 65 & 1 & 1 & 0 & 0 & 1 & 8 & 77 & 70 & 30.3 & 0 & 0.01 & 10.8 & 10.95 \\
\hline Wall_27/28_Bay & & & & & & & & & & & 30.4 & & & & \\
\hline $6-$ & 17.67 & 65 & 1 & 0 & 0 & 0 & 1 & 70 & 65 & 86 & 4 & 0 & 0 & 9.7 & 9.4 \\
\hline Wall_27/28_Bay & & & & & & & & 91. & & & & & & & \\
\hline 6 & 17.67 & 65 & 1 & 0 & 0 & 0 & 0 & 5 & 72 & 53 & 30.3 & 0 & 0 & 13.9 & 10.85 \\
\hline & & & & & & & & 87. & - & & 29.9 & & & & \\
\hline Wall_29_Bay56 & 20.5 & 195 & 1 & 0.9 & 1 & 0 & 0 & 3 & 24 & 1 & 7 & 0 & 0 & 21 & 17.9 \\
\hline Wall_32B_Bay11 & & & & & & & & & 8. & & 30.0 & & & & \\
\hline $7 \_1$ & 34 & 154 & 1 & 0.4 & 1 & 0 & 0 & 79 & 5 & 3 & 9 & 0 & 0 & 20 & 18.75 \\
\hline Wall_32B_Bay11 & & & & & & & & 70. & & & 30.0 & & & & \\
\hline 7_2 & 34 & 154 & 1 & 0 & 1 & 0 & 1 & 5 & 43 & 37 & 5 & 0 & 0 & 15.9 & 16.55 \\
\hline & & & & & & & & 69. & 43 & & 30.0 & & & & \\
\hline Wall_32B_Bay76 & 21.5 & 162 & 1 & 0 & 0 & 1 & 1 & 1 & .2 & 39 & 1 & 1.34 & 2.79 & 12.7 & 12.15 \\
\hline Wall_32B_Bay14 & & & & & & & & & & & 30.0 & & & & \\
\hline 2_1 & 17.67 & 158 & 1 & 0 & 0 & 0 & 1 & 79 & 79 & 100 & 4 & 0 & 0 & 2.6 & 6.85 \\
\hline Wall_32B_Bay14 & & & & & & & & 71. & 70 & & 30.1 & & & & \\
\hline $2 \_2$ & 17.67 & 158 & 1 & 0 & 0 & 0 & 1 & 2 & .9 & 99 & 8 & 0 & 0 & 10.4 & 8.9 \\
\hline Wall_32B_Bay14 & & & & & & & & 85. & 69 & & 30.0 & & & & \\
\hline $2 \_3$ & 17.67 & 158 & 1 & 1.1 & 0 & 0 & 0 & 8 & .8 & 59 & 1 & 0 & 0 & 10.5 & 11.55 \\
\hline & & & & & & & & 74. & 73 & & 30.1 & & & & \\
\hline Wall_30_Bay4 & 23.5 & 28 & 1 & 0 & 0 & 1 & 1 & 3 & .9 & 99 & 9 & 0 & 0 & 17.8 & 14.3 \\
\hline Wall_10_Bay35_ & & & & & & & & 79. & 74 & & 29.0 & & & & \\
\hline 1 & 24.25 & 10 & 1 & 0 & 1 & 0 & 0 & 2 & .6 & 86 & 8 & 0 & 0 & 16.6 & 11 \\
\hline Wall_10_Bay35_ & & & & & & & & 10 & 75 & & 29.0 & & & & \\
\hline 2 & 24.25 & 10 & 1 & 0 & 1 & 0 & 0 & 5 & .4 & 39 & 8 & 0 & 0 & 14.4 & 10.75 \\
\hline Wall_10_Bay35_ & & & & & & & & 79. & 74 & & & & & & \\
\hline 3 & 24.25 & 10 & 1 & 0 & 1 & 0 & 0 & 3 & .4 & 85 & 29.2 & 0 & 0 & 16.1 & 11.4 \\
\hline Wall_4ABC_Bay1 & & & & & & & & & 75 & & 29.0 & & & & \\
\hline $05 \_1$ & 22.5 & 27 & 1 & 0 & 1 & 0 & 0 & 90 & .2 & 62 & 8 & 0 & 0 & 12.8 & 10.35 \\
\hline
\end{tabular}




\begin{tabular}{|c|c|c|c|c|c|c|c|c|c|c|c|c|c|c|c|}
\hline Wall_4ABC_Bay1 & & & & & & & & 78. & 75 & & 29.1 & & & & \\
\hline $05 \_2$ & 22.5 & 27 & 1 & 0 & 1 & 0 & 0 & 4 & .9 & 92 & 9 & 0 & 0 & 19.2 & 14.35 \\
\hline Wall_4E_Bay107 & & & & & & & & 89. & & & 30.0 & & & & \\
\hline-1 & 14.5 & 24 & 1 & 6 & 1 & 0 & 0 & 5 & 68 & 50 & 7 & 0 & 0 & 15.2 & 11.55 \\
\hline Wall_4E_Bay107 & & & & & & & & 81. & & & 30.1 & & & & \\
\hline${ }^{2}$ & 14.5 & 24 & 1 & 0 & 1 & 0 & 0 & 3 & 74 & 79 & 5 & 0 & 0 & 18.9 & 11.05 \\
\hline & & & & & & & & 89. & & & 30.0 & & & & \\
\hline Wall_9_Bay41_1 & 12.5 & 23 & 1 & 6 & 1 & 0 & 0 & 4 & 68 & 49 & 7 & 0 & 0 & 14.4 & 8.35 \\
\hline & & & & & & & & 81. & & & 30.1 & & & & \\
\hline Wall_9_Bay41_2 & 12.5 & 23 & 1 & 0 & 1 & 0 & 0 & 4 & 74 & 79 & 5 & 0 & 0 & 15 & 9.8 \\
\hline Wall_5B_Bay187 & & & & & & & & 90. & & & 30.0 & & & & \\
\hline & 13.5 & 20 & 1 & 11 & 1 & 0 & 0 & 5 & 68 & 48 & 6 & 0 & 0 & 16.7 & 16.85 \\
\hline Wall_5B_Bay187 & & & & & & & & & & & 30.1 & & & & \\
\hline 2 & 13.5 & 20 & 1 & 2 & 1 & 0 & 0 & 81 & 73 & 79 & 5 & 0 & 0 & 19.2 & 14.6 \\
\hline
\end{tabular}


APPENDIX B

Constructability Survey

\section{Survey on the constructability of three traffic noise barriers}

This survey seeks your opinions on how easy to construct for three types of traffic noise barriers: (1) Interlocking Stee Panels, (2) Precast Concrete Panels, and (3) Styrofoam Panels.

How would you rate the level of constructability for the traffic noise barrier with Interlocking Steel Panels (ShadowRib)?

$\begin{array}{ccccccc}\begin{array}{c}\text { Very easy to } \\ \text { construct }\end{array} & 0 & 1 & 2 & 3 & 4 & 5\end{array}$

How would you rate the level of constructability for the traffic noise barrier with Precast Concrete Panels (Duratek Wall Systems)?

$\begin{array}{ccccccc}\begin{array}{c}\text { Very easy to } \\ \text { construct }\end{array} & 1 & 2 & 3 & 4 & 5 & \\ \text { Very difficult to } \\ \text { construct }\end{array}$

How would you rate the level of constructability for the traffic noise barrier with Styrofoam Panels (Noise D-Fence Paragon)?

$\begin{array}{ccccccc}\begin{array}{c}\text { Very easy to } \\ \text { construct }\end{array} & 0 & 1 & 2 & 3 & 4 & 5\end{array}$

